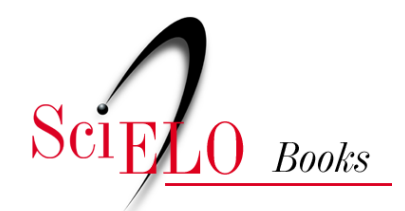

\title{
Situando Duque de Caxias no contexto metropolitano da Baixada Fluminense de cidade-dormitório a cidade plena
}

\author{
Leandro Almeida da Silveira \\ Miguel Ângelo Campos Ribeiro
}

\section{SciELO Books / SciELO Livros / SciELO Libros}

SILVEIRA, L.A., and RIBEIRO, M.Â.C. Situando Duque de Caxias no contexto metropolitano da Baixada Fluminense: de cidade-dormitório a cidade plena. In: MARAFON, G.J., and RIBEIRO, M.A. orgs. Revisitando o território fluminense, VI [online]. Rio de Janeiro: EDUERJ, 2017, pp. 209-258. ISBN: 978-85-7511-457-5. https://doi.org/10.7476/9788575114575.0012.

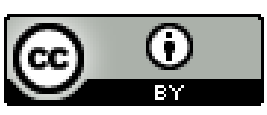

All the contents of this work, except where otherwise noted, is licensed under a Creative Commons Attribution 4.0 International license.

Todo o conteúdo deste trabalho, exceto quando houver ressalva, é publicado sob a licença Creative Commons Atribição $\underline{4.0}$.

Todo el contenido de esta obra, excepto donde se indique lo contrario, está bajo licencia de la licencia $\underline{\text { Creative Commons }}$ $\underline{\text { Reconocimento 4.0. }}$. 


\title{
Situando Duque de Caxias no contexto metropolitano da Baixada Fluminense: de cidade-dormitório a cidade plena ${ }^{1}$
}

\author{
Leandro Almeida da Silveira ${ }^{2}$ \\ Miguel Ângelo Campos Ribeiro ${ }^{3}$
}

ocalizado na periferia da antiga capital federal Rio de Janeiro, o município de Duque de Caxias
(DC), que pode ser visto na Figura 1, apresenta indicadores econômicos e sociais bastante confli-
tantes. Por um lado, possui o terceiro maior PIB entre os municípios do estado do Rio de Janeiro
e o $24^{\circ}$ entre todos os do Brasil (IBGE, 2015). Ao mesmo tempo, no Índice de Desenvolvimento
Humano Municipal (IDHM), Caxias ocupa as $49^{\mathrm{a}}$ e $1.574^{\mathrm{a}}$ (PNUD, 2013) colocações no estado e
no país, respectivamente. Portanto, nota-se uma situação social extremamente precária e aparente-

1 Dedicamos este artigo à memória do Prof. Dr. Maurício de Almeida Abreu, em agradecimento pela orientação e a participação direta na formação de um de seus autores, por sua enorme contribuiçãoo aos estudos de Geografia do Rio de Janeiro e por ter sido tantas vezes fonte de inspiração para nós e tantos outros geógrafos.

2 Leandro Almeida da Silveira concluiu o bacharelado e a licenciatura em Geografia pela Universidade Federal do Rio de Janeiro (2009), tendo se tornado especialista em Políticas Públicas no Estado do Rio de Janeiro (2013) e mestre em Geografia, ambos pela Universidade do Estado do Rio de Janeiro (2016). Atualmente, é professor do Ensino Básico e Tecnológico no Colégio Pedro II, campus Duque de Caxias.

3 Miguel Ângelo Campos Ribeiro graduou-se em Geografia pela Universidade Federal Fluminense (1971), concluiu o mestrado em Geografia pela Universidade Federal do Rio de Janeiro (1982) e o doutorado em Geografia pela Universidade Federal do Rio de Janeiro (1998). Atualmente é professor associado da Universidade do Estado do Rio de Janeiro. Com experiência na área de Geografia Humana, atua principalmente com o estado do Rio de Janeiro, focando nas temáticas do Turismo Urbano e Rural, na rede de localidades centrais, na regionalização e na organização espacial. Atua também em pesquisas voltadas à atividade de prostituição na cidade do Rio de Janeiro. 
mente contrastante com a grande produção de riqueza de DC. Ademais, é possível observar também profundas disparidades dentro do próprio município.

Figura 1. Localização do município de Duque de Caxias

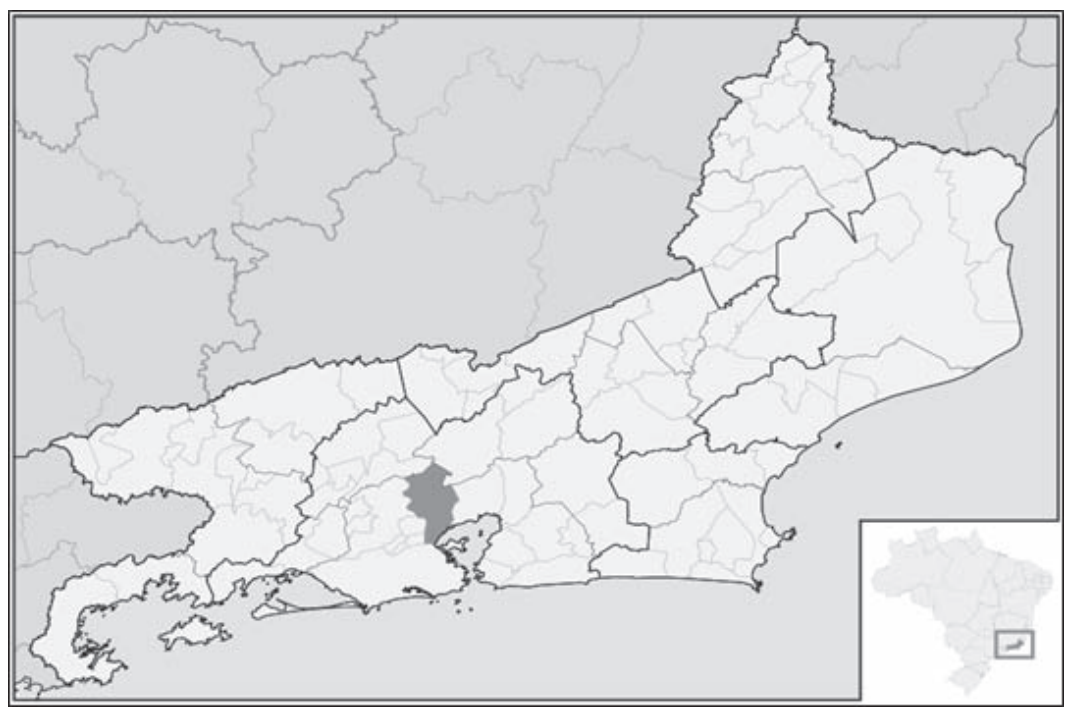

Fonte: http://pt.wikipedia.org/wiki/Ficheiro:RiodeJaneiro_Municip_DuquedeCaxias.svg.

Este artigo traça um panorama socioeconômico do município de Duque de Caxias. Consideramos que é importante entender a dinâmica atual e a espacialidade da economia municipal, incluindo as principais fontes de arrecadação e de que forma essa renda se distribui pelo município, uma vez que o vigor expresso pelos números do PIB é bastante concentrado em determinadas localidades. Assim, buscamos captar os aspectos contemporâneos do município à luz de sua evolução histórica, com destaque para o período do século XX, momento em que a população e a desordem urbana se expandiram de forma acelerada nessa localidade.

No entanto, Duque de Caxias, São João de Meriti, Nilópolis e Nova Iguaçu integravam um único município até a década de 1940. Durante muito tempo, todo o território que "se estende dos limites serranos de Miguel Pereira a Petrópolis e destes até o contorno da Baía de Guanabara, na foz do rio Meriti, e deste aos contrafortes do Gericinó até Itaguaî" (Nogueira, 2008, p.5) fazia parte do 
município de Nova Iguaçu. Em 1943, porém, a emancipação do então distrito de Duque de Caxias deu início a uma sequência de fragmentaçōes ${ }^{4}$ na Baixada Fluminense ${ }^{5}(\mathrm{BF})$.

Portanto, durante a maior parte de sua existência, a história da ocupação do município de Duque de Caxias se confunde com a de seus vizinhos - o município do Rio de Janeiro e sua área de expansão no entorno imediato, ou seja, os demais municípios da Baixada Fluminense. Inseridos na Região Metropolitana ${ }^{6}$ do Rio de Janeiro (RMRJ), tais municípios compartilham entre si uma série de características em comum. Por isso mesmo, para compreender a situação socioeconômica e as desigualdades que surgiram em Duque de Caxias, consideramos necessário revisitar o processo de construção desse município e da BF. Portanto, apresentamos também, de forma breve, a formação histórica e territorial dessa região e suas principais características.

\section{Panorama geográfico e socioeconômico atual de Duque de Caxias}

Situado na Baixada Fluminense, Duque de Caxias tem como limites os municípios de Miguel Pereira, Magé, Rio de Janeiro, São João de Meriti e Nova Iguaçu. Seu território é dividido em quatro distritos: Duque de Caxias $\left(1^{\circ}\right)$, Campos Elíseos $\left(2^{\circ}\right)$, Imbariê $\left(3^{\circ}\right)$ e Xerém $\left(4^{\circ}\right)$, que, por sua vez, se dividem em diversos bairros, como registra a Figura 2.

\footnotetext{
${ }^{4}$ Com mais de $1.500 \mathrm{~km}^{2}$, o município de Nova Iguaçu passou a sofrer grande pressão populacional e política, clamando por melhorias urbanas, como saneamento, água, equipamentos de saúde e de educação, principalmente após a Segunda Guerra Mundial, o que levou ao início do processo de emancipação na Baixada Fluminense. De acordo com Marcus Nogueira (2008, p. 5), "esse fenômeno alijou, de forma rápida e brutal, as históricas e tradicionais famílias que ocupavam a região. Desaparecem os Soares, os Souza e Mello, os Telles de Menezes, os Tavares Guerra, os Coelhos da Rocha, entre outros", consolidando novas elites e forças políticas no espaço da Baixada.

5 O topônimo Baixada Fluminense tem origem no latim flumineus, estando relacionado às expressóes "do rio" e "das águas". Essas expressões foram empregadas pelos colonizadores portugueses por conta do caráter geomorfológico da área, em "cujo terreno pantanoso abrigavam-se os índios tupinambás, da aldeia dos índios jacutingas ou iacotins”(Lima, 2010, p.140). Outras aplicações do termo Baixada Fluminense serão apresentadas mais adiante.

${ }^{6}$ Com o ingresso recente dos municípios de Cachoeiras de Macacu e Rio Bonito em dezembro de 2013, a Região Metropolitana do Rio de Janeiro passou a incluir 21 municípios: Rio de Janeiro, Belford Roxo, Duque de Caxias, Guapimirim, Itaboraí, Japeri, Magé, Maricá, Mesquita, Nilópolis, Niterói, Nova Iguaçu, Paracambi, Queimados, São Gonçalo, São João de Meriti, Seropédica, Tanguá, Itaguaí, Rio Bonito e Cachoeiras de Macacu. Em 2015, esse conjunto de municípios abrigava cerca de 12 milhões de habitantes.
} 
Figura 2. Bairros e distritos de Duque de Caxias

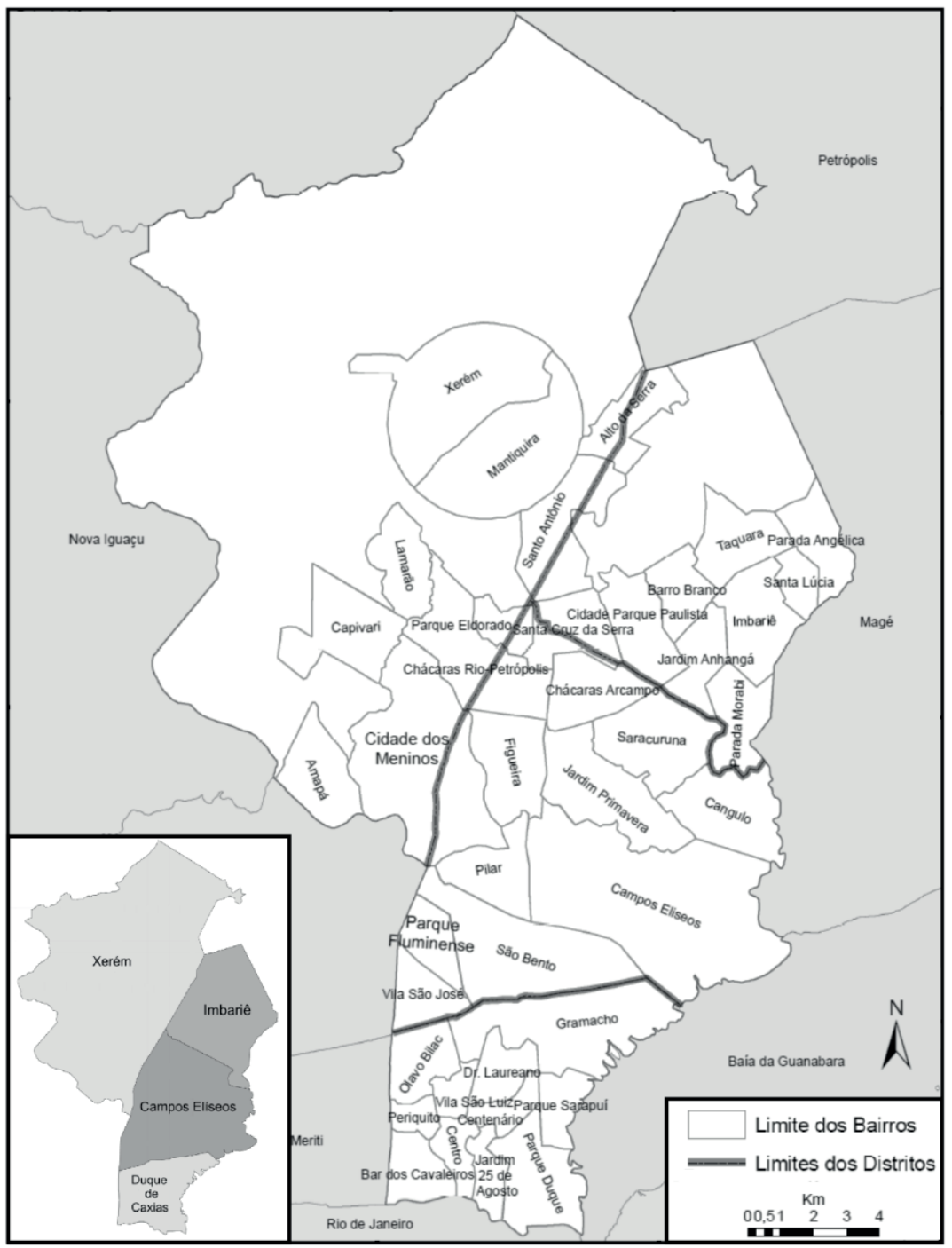

Fonte: Adaptado de Tenreiro (2012, pp. 21-2).

Segundo estimativa atualizada do IBGE (2015), atualmente o município concentra uma população de 882.729 residentes, o que o torna um dos mais populosos do estado do Rio de Janeiro $\left(3^{\circ}\right)$, à retaguarda somente da capital, Rio de Janeiro, e de São Gonçalo; e do Brasil $\left(18^{\circ}\right)$, possuindo mais habitantes do que diversas capitais estaduais brasileiras. A população se localiza principalmente nos bairros situados nos distritos 1 e 2 (Gráfico 1), mais próximos à capital, Rio de Janeiro, e os primeiros a sofrerem o processo de loteamento de suas terras. 
Situando Duque de Caxias no contexto metropolitano da Baixada Fluminense

Gráfico 1. População de Duque de Caxias por distrito (2010)

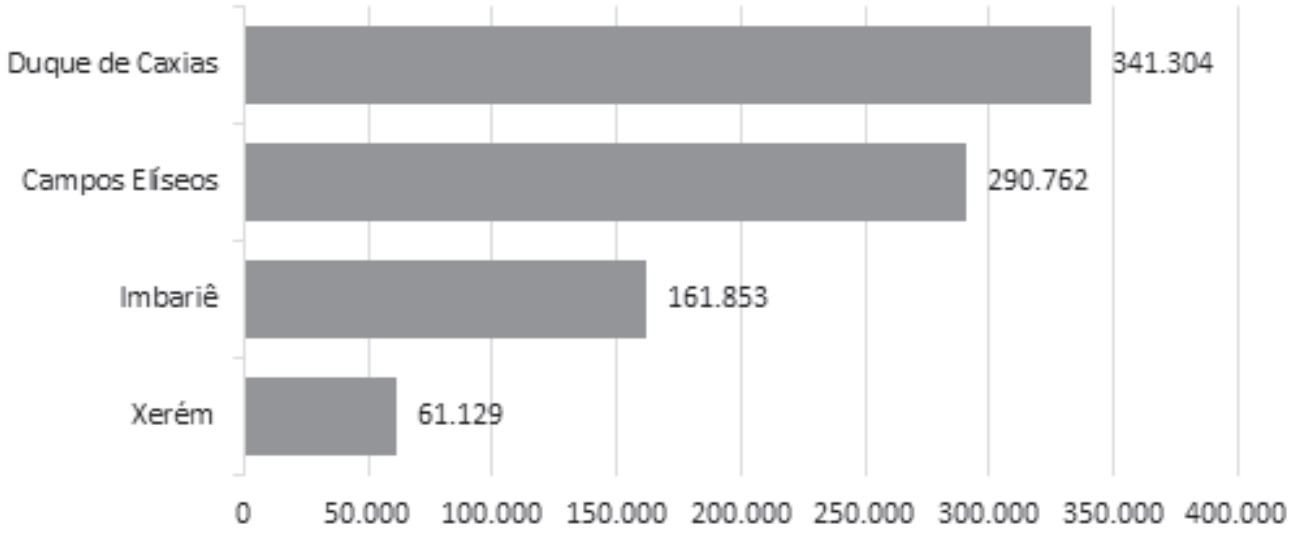

Fonte: Elaborado a partir de dados do TCE (2014, p. 11).

A quase totalidade dos munícipes locais ocupa áreas urbanas (Tabela 1). Essa situação condiz com sua posição de município metropolitano, seguindo o padrão predominante na maior parte das demais municipalidades do estado do Rio de Janeiro, essencialmente urbano.

Tabela 1. População urbana e rural de Duque de Caxias (1940-2010)

\begin{tabular}{|l|c|c|c|c|c|}
\hline Ano & $\begin{array}{c}\text { Populaçáo } \\
\text { Total }\end{array}$ & População Urbana & \% & $\begin{array}{c}\text { Populaçáo } \\
\text { Rural }\end{array}$ & $\mathbf{( \% )}$ \\
\hline 1940 & 28.328 & 23.963 & 84,6 & 4.365 & 15,4 \\
\hline 1950 & 92.459 & 74.565 & 80,4 & 17.894 & 19,6 \\
\hline 1960 & 241.026 & 176.306 & 72,1 & 67.313 & 27,9 \\
\hline 1970 & 431.397 & 404.496 & 93,8 & 26.901 & 6,2 \\
\hline 1980 & 575.814 & 555.208 & 96,4 & 20.606 & 3,6 \\
\hline 1991 & 667.821 & 664.745 & 99,5 & 3.673 & 0,5 \\
\hline 2000 & 775.456 & 772.327 & 99,6 & 3.129 & 0,4 \\
\hline 2010 & 855.048 & 852.138 & 99,7 & 2.910 & 0,3 \\
\hline
\end{tabular}

Fonte: Elaborado a partir de dados dos Censos do IBGE e de Beloch (1986).

Assim como observado nos demais municípios da Baixada, pode-se notar diariamente uma intensa migração pendular de cidadãos caxienses em direção ao Rio de Janeiro. Enquanto isso, a vida social e o comércio de varejo estão concentrados, predominantemente, nos fins de semana. Entretanto, apesar dessas características, atualmente não é adequado classificar Duque de Caxias como uma cidade-dormitório. ${ }^{7}$ Entre suas características, o município se distingue de outros da Baixada e da Região Me-

7 Ver Lacerda (2008). 
tropolitana por apresentar vida econômica relativamente própria e polarizar outros municípios menores do entorno, especialmente Belford Roxo, São João de Meriti e Magé. De acordo com Simões:

Estas cidades externas [...] reproduzem na escala regional o modelo de organização socioespacial da metrópole e da hierarquização das relações sociais, econômicas e políticas que se estabelecem entre esses núcleos e aqueles que acabam por ser polarizados. [...] Desse modo, Nova Iguaçu e Duque de Caxias possuem, cada uma delas, a sua centralidade e um território subordinado, onde as relações socioeconômicas e políticas se instalaram em meio a conflitos entre os grupos de interesse dos núcleos dominantes e dos núcleos dominados (Simōes, 2007, p. 193).

Outra diferença fundamental de Duque de Caxias em relação aos muncípios vizinhos é o tamanho e o peso de sua economia sobre o PIB do estado do Rio de Janeiro, como se nota na Figura 3.

Figura 3. Contribuição dos municípios para o PIB do estado do RJ (2010)

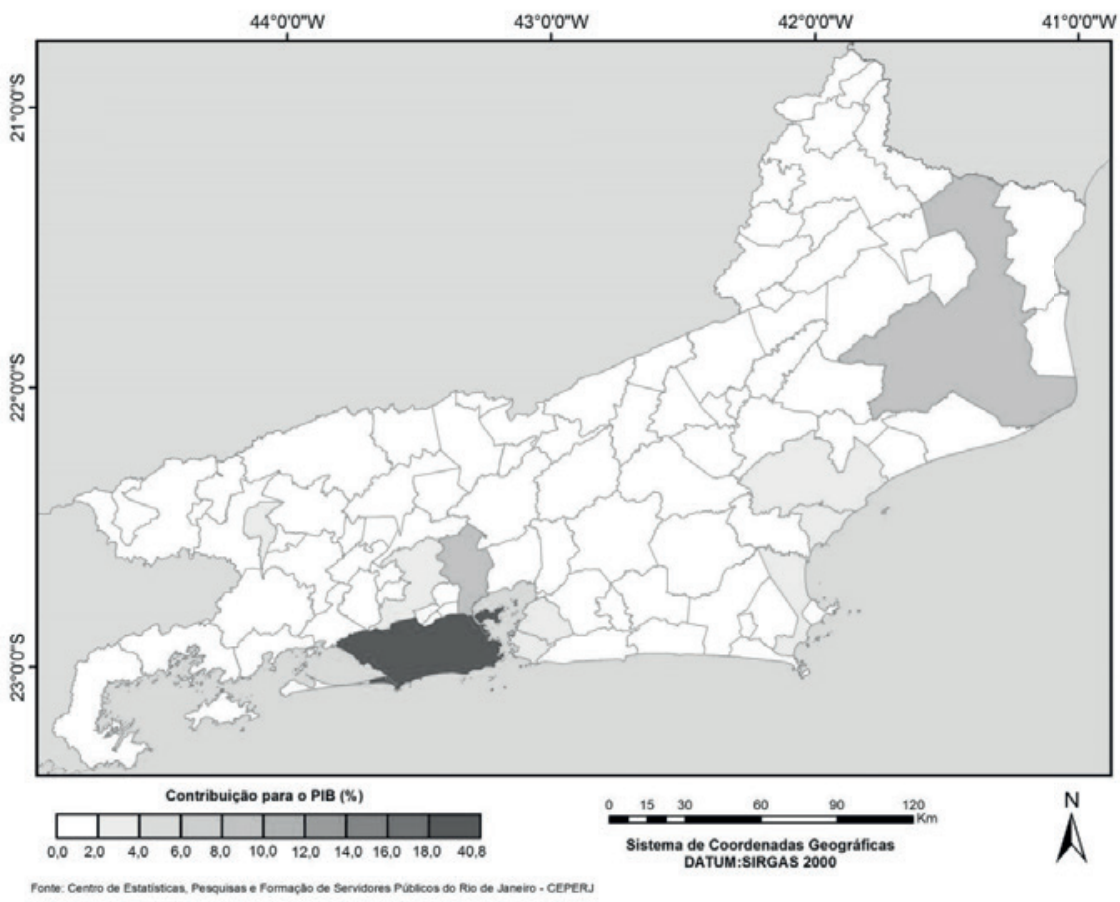

Fonte: Tenreiro (2012, p. 17).

Segundo o IBGE (2015), Duque de Caxias possui um PIB de R \$ 23,4 bilhões, o maior valor de todos os municípios da Baixada Fluminense, o segundo maior da RMRJ, o terceiro do estado do Rio de 
Janeiro e o $24^{\circ}$ entre todos os municípios do Brasil (IBGE, 2015). ${ }^{8}$ Tal destaque no campo da economia já ocorre há algumas décadas, especialmente a partir dos anos 1960, quando ocorreu a instalação da Refinaria de Duque de Caxias (Reduc) na cidade. Durante a década de 1980, o município apresentou crescimento econômico de 32,5\%. No biênio 1997-1998, num universo de mais de cinco mil municípios, foi um dos dez com maior crescimento econômico (Petrakis, 2009). Como se observa no Gráfico 2, a maior parte da economia caxiense corresponde ao setor de serviços. ${ }^{9}$ A indústria ocupa a segunda colocação, enquanto a agropecuária é responsável por uma fatia mínima da geração de riqueza, ${ }^{10}$ sendo praticada apenas em pequenas áreas de Xerém, $4^{\circ}$ distrito do município (Simōes, 2015).

Gráfico 2. Duque de Caxias: participação dos setores da economia no PIB (2013)

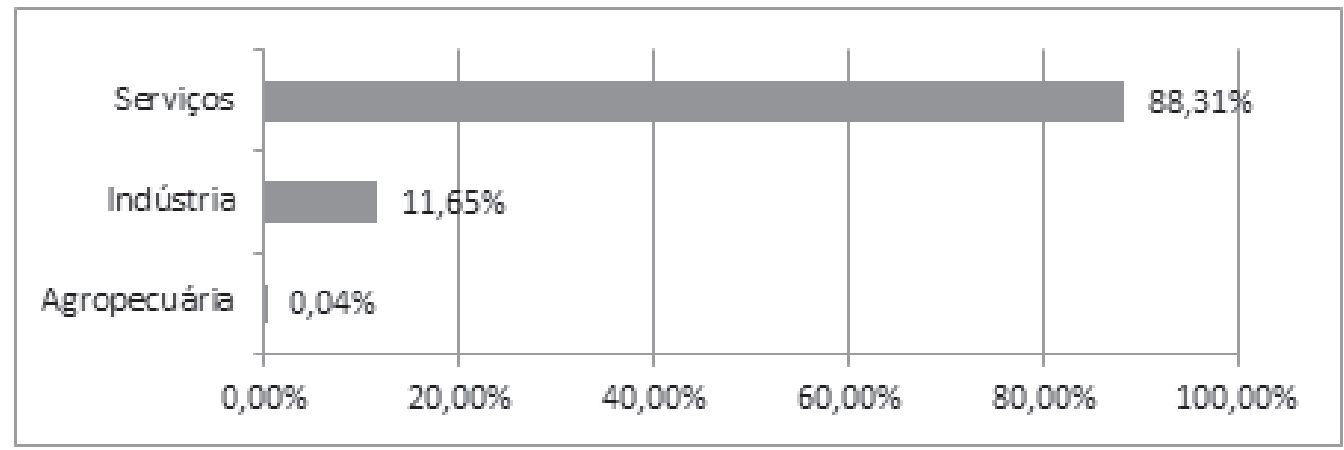

Fonte: Elaborado com dados do IBGE Cidades (2015).

O centro comercial de Caxias é um dos mais importantes e diversificados do estado do Rio de Janeiro, com uma variedade de bens e serviços presente apenas nos maiores centros comerciais dos municípios de Nova Iguaçu, Niterói e Rio de Janeiro. Há também uma série de outras atividades econômicas desenvolvidas no município e em processo de expansão, dentre as quais destacam-se: o forte crescimento dos empreendimentos de transporte e logística; a instalação de grandes centros de distribuição das Casas Bahia, Carrefour e Hortifruti; o parque gráfico do jornal O Globo; as recém-chegadas fábricas da empresa alimentícia Bunge (Moinho Carioca) e da produtora de insumos navais Rolls Royce; a Coca-Cola, cuja fábrica está em fase final de construção; e os centros comerciais Caxias Shopping e Shopping Outlet Premium.

Na Figura 4, observamos a distribuição espacial de algumas das principais empresas e empreendimentos industriais e comerciais instalados ou em instalação no município. Percebe-se que

\footnotetext{
8 Os dados foram obtidos no sítio eletrônico IBGE Cidades em 2015 e podem ser consultados em http://www. cidades.ibge.gov.br, embora correspondam a uma base de dados de 2012-2013.

9 Inclui comércio, administração, saúde e educação pública e seguridade social

${ }^{10}$ Segundo Beloch (1986), desde a década de 1940 a indústria é uma atividade mais importante do que a agricultura em Duque de Caxias.
} 
essas instalações se situam, em sua maioria, nas áreas do $1^{\circ}$ e $2^{\circ}$ Distritos e nas margens da rodovia Washington Luiz (BR-040).

Figura 4. Principais empreendimentos no município de Duque de Caxias

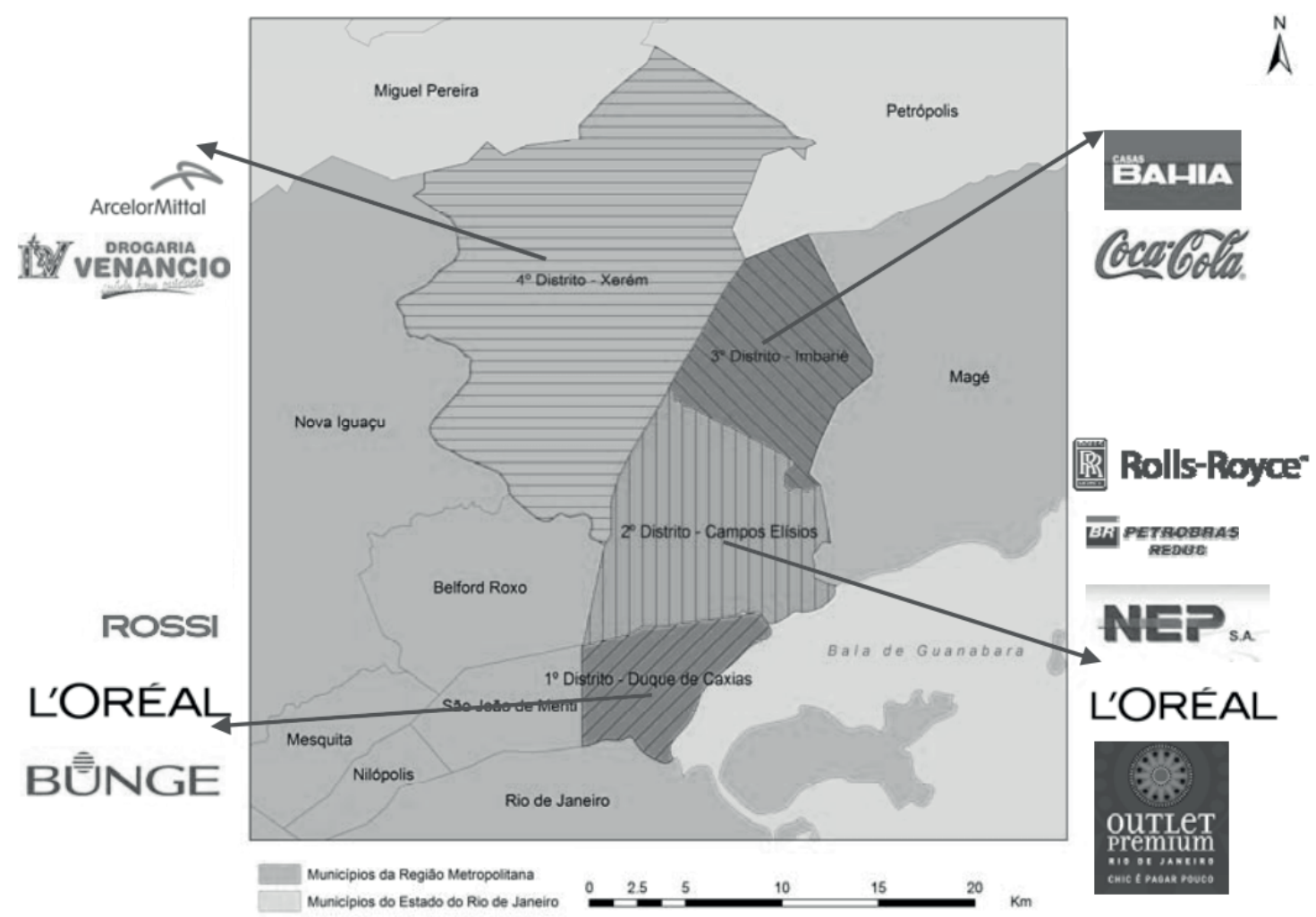

Fonte: Adaptado de Silva (2014, p. 120).

A grande presença de empresas de diversos setores pode ser explicada pela existência de amplos espaços no município, favoráveis à instalação de grandes empreendimentos. Outro elemento diferencial é a privilegiada posição geográfica caxiense, próxima a importantes vias de acesso e ao mercado consumidor do Rio de Janeiro. Tais razões podem ser encontradas na entrevista concedida ao jornal $O$ Dia por Níveo Maluf, diretor da Bunge do Brasil, empresa de alimentos que está investindo R \$ 500 milhões na construção do novo Moinho Fluminense. Segundo Maluf:

[...] A escolha por Duque de Caxias foi estratégica, sendo a cidade que ofereceu as melhores condições de atuação e logística para receber a transferência do atual Moinho Fluminense e o Centro de Distribuição Rio, que serão transferidos para uma área de 90 mil metros quadrados. A rodovia Washington Luiz já é conhecida como a esquina do Brasil (Gimenez, 2014. Publicado em O Dia, 08 de abril de 2014, edição on-line). 


\section{Situando Duque de Caxias no contexto metropolitano da Baixada Fluminense}

Entre as condições favoráve is de logística, estão a distância de apenas $17 \mathrm{~km}$ até o núcleo da metrópole fluminense e a localização limítrofe com municípios como Belford Roxo, São João de Meriti, Nova Iguaçu, Petrópolis e Magé. No que diz respeito à rede de transportes, o município de Caxias se beneficia por ser cortado por duas rodovias federais (a BR-040 e a BR-116) e uma estadual (RJ-071 ou Linha Vermelha); pela proximidade com outras vias importantes, como a avenida Brasil e a Linha Amarela; e pela curta distância até o aeroporto internacional Tom Jobim. Além disso, é possível apontar também a economia de aglomeração formada, uma vez que a chegada de uma série de empresas tem estimulado a instalação de terminais de cargas e de logística.

Também merece destaque o Polo Moveleiro de Duque de Caxias, que atualmente ocupa cerca de $50 \mathrm{mil} \mathrm{m}^{2}$ no município. Sua origem remonta ao ano de 1994, quando houve a instalação de fá-

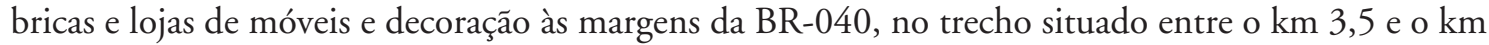
7, nas imediações dos bairros Jardim Gramacho e Vila São Luiz (Figuerêdo, 2010). Cabe mencionar ainda o setor de vestuário, pois diversos bairros do $1^{\circ}$ Distrito ${ }^{11}$ contam com confecções cuja produção de roupas se destina a grandes polos ${ }^{12}$ atacadistas e varejistas. ${ }^{13}$ De acordo com Santos (2015), predominam pequenas unidades industriais com menos de vinte funcionários, repetindo o modelo observado nas empresas do polo moveleiro.

No setor secundário, porém, nenhuma atividade é tão importante para Duque de Caxias quanto a indústria química, responsável por cerca de $78 \%$ do total das atividades industriais estabelecidas no município (Ceperj, 2014; Sebrae, 2015). As responsáveis diretas por tamanho peso econômico são a Refinaria de Duque de Caxias (Reduc) e os polos petroquímico e gás-químico a ela associados, que fazem da cidade o principal espaço de produção de derivados de petróleo do estado do Rio de Janeiro (Ceperj, 2013). Portanto, apesar da relativa diversidade do setor industrial caxiense, formado por "mais de oitocentas fábricas" (Costa, 2012, p.267), é indiscutível a dependência econômica em relação à Reduc, principal empreendimento da cidade e marco do processo de industrialização estabelecido no município.

Localizada à margem direita da Rodovia BR-040, sentido Rio-Petrópolis, a Reduc foi inaugurada em 1961, sendo atualmente responsável por 1.800 empregos diretos e 10 mil vagas indiretas (Lafraia, 2011). Junto a ela, estão o polo petroquímico, criado nos anos 1970 e 1980, e o polo gás-químico, unidade de fabricação de polímeros inaugurada em 2005. Pode-se afirmar que a empresa alavanca a economia caxiense de forma direta e indireta, pois, além de sua grande produção, as in-

\footnotetext{
${ }^{11}$ Segundo Marcelo Santos (2015), destacam-se os bairros Bar dos Cavaleiros, Periquitos e Centenário.

${ }^{12}$ Situados na rodovia Washington Luiz, no calçadão de Caxias e em pequenos centros comerciais dos bairros Santa Cruz da Serra, Saracuruna, Jardim Primavera, Gramacho e Figueira.

${ }^{13}$ Cabe citar que, ao contrário do padrão identificado em outros municípios vizinhos, em Duque de Caxias o comércio atacadista gera maior faturamento do que o varejista (Plantek, 1999). Entre as razões que explicam esse fenômeno, está o fato de que o comércio varejista no município atende a um mercado consumidor composto, em sua maioria, por pessoas de baixo poder aquisitivo. Além disso, um dos fatores é o alto grau de informalidade dos pequenos estabelecimentos que atuam nesse tipo de atividade (Sebrae, 2015). Segundo Costa (2012, p. 269), porém, "a inexpressiva participação do comércio varejista de Duque de Caxias no seu PIB é explicada pelos [mais] altos valores da Refinaria do que pelo seu baixo desenvolvimento".
} 
dústrias que a cercam dependem de suas matérias-primas. Ademais, de acordo com Simōes (2015), o comércio e boa parte dos serviços têm parte de sua renda gerada pela venda de produtos e serviços prestados a essas empresas. Nesse contexto, a elevada riqueza produzida no município acaba por fazer com que a renda per capita (Gráfico 3), de cerca de R \$ 30 mil, seja a segunda maior da RMRJ, mesmo sendo a população caxiense muito numerosa.

Gráfico 3. Ranking do PIB per capita de municípios da RMRJ (2010)

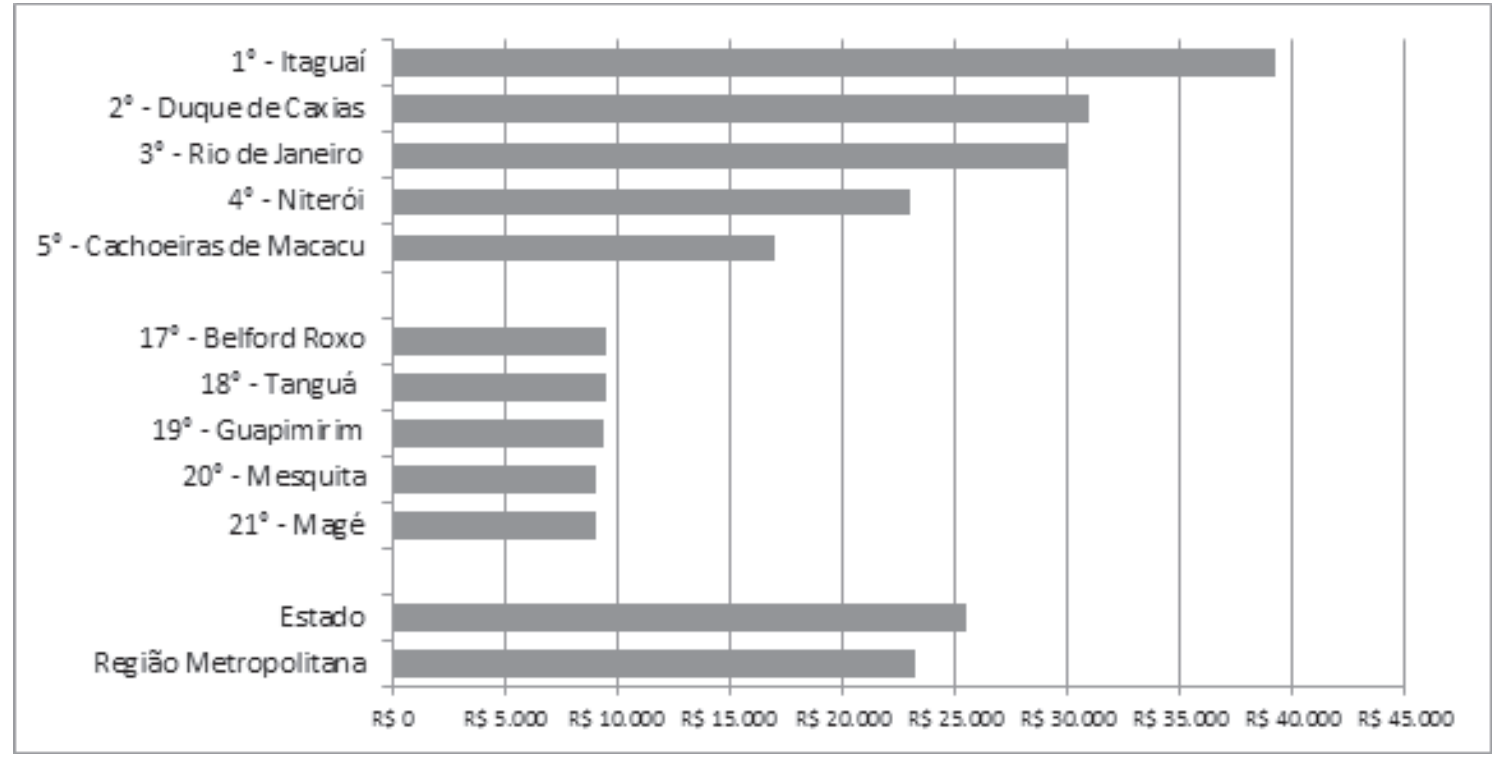

Fonte: Elaborado com dados do Ceperj (2013).

O patamar privilegiado ocupado por Duque de Caxias no ranking do PIB per capita se repete quando comparamos os salários médios pagos na Região Metropolitana. A Figura 5 mostra que DC se encontra em posição superior a vários outros municípios, sendo superado apenas por Rio de Janeiro e Seropédica. ${ }^{14}$

\footnotetext{
${ }^{14}$ Acreditamos que a situação de Seropédica nesse ranking seja resultado da combinação entre população reduzida e salários elevados pagos a professores, técnicos e demais funcionários pela Universidade Federal Rural do Rio de Janeiro, cujo campus principal se localiza no município.
} 
Figura 5. Salário médio nos municípios da RMRJ (2010)

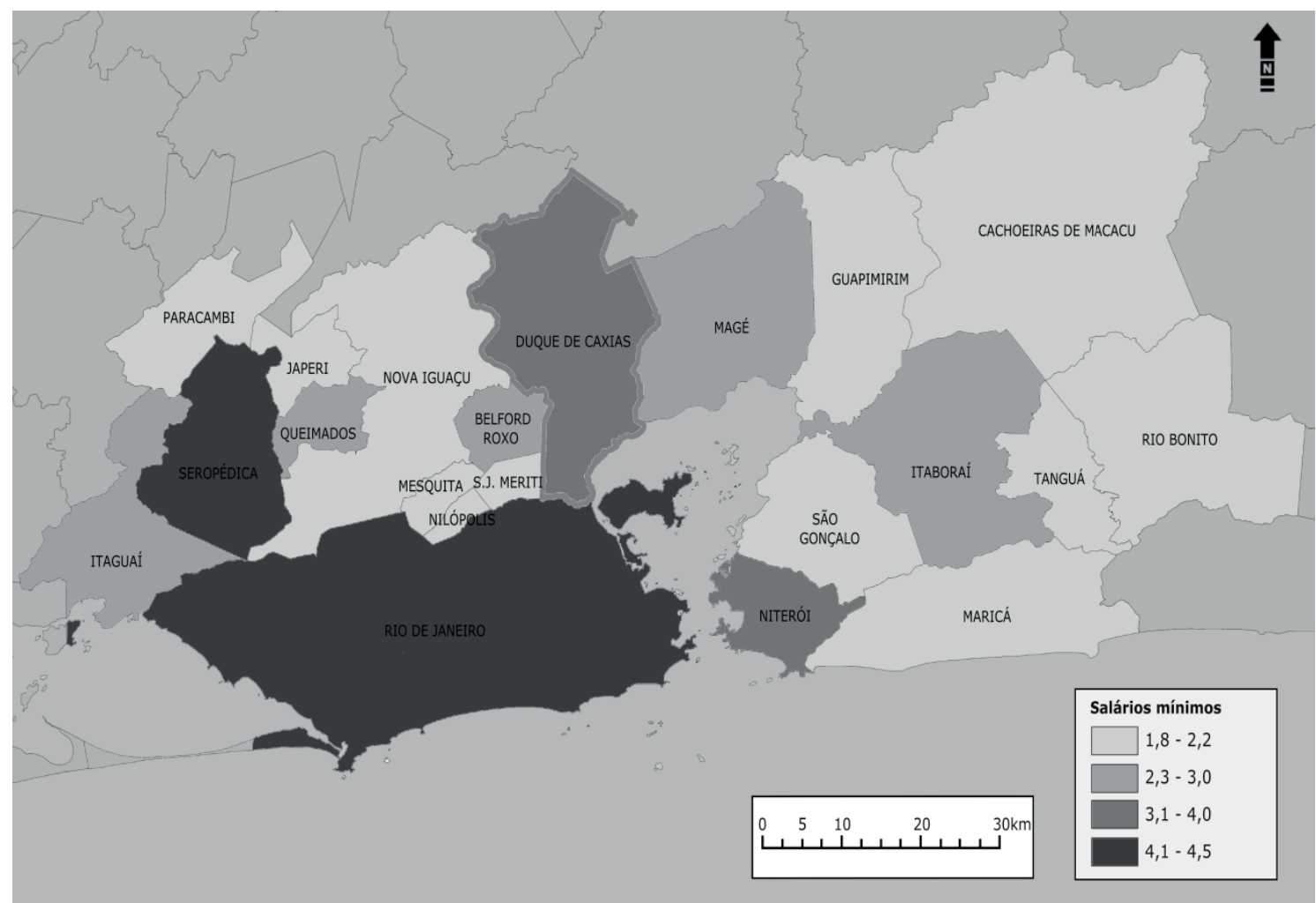

Fonte: Leandro Silveira. Elaborado com dados do IBGE (2010).

Além disso, Caxias se encontra no mesmo nível de salários médios de Niterói, município com qualidade de vida reconhecidamente elevada. Entretanto, a impressão de que ambos desfrutam da mesma situação relativamente confortável é enganosa. Afinal, o maior empregador da cidade de $\mathrm{Du}-$ que de Caxias é a Petrobras, cujo empreendimento central é uma refinaria. Portanto, os demais setores, como administração, gerência e pesquisa científica, responsáveis pela maior parte dos cargos com salários mais elevados, encontram-se fora da cidade, especialmente no centro do Rio de Janeiro e na ilha do Fundão.

Outro indicador que nos leva a refletir a respeito do tamanho do retorno financeiro resultante das atividades da Reduc em Duque de Caxias é o dos valores gerados pelas instituições financeiras. Segundo o TCE (2014), o movimento bancário corresponde a apenas 0,61\% do PIB municipal. A elevada movimentação financeira da Petrobras poderia ser um fator de alavancagem do setor bancário municipal, mas é realizada integralmente nas agências bancárias do Rio de Janeiro (Lafraia, 2011). Além disso, parte significativa dos empregos de alta qualificação - e, por conseguinte, de maior remuneração - gerados pela indústria química municipal acaba sendo ocupada por moradores de outras cidades, notadamente do Rio de Janeiro. A falta de instituiçóes de ensino que formem mão de obra 
qualificada para o setor e a baixa escolaridade média dos cidadãos caxienses acabam, portanto, por reduzir o ganho socioeconômico que poderia ser obtido pelo município com a presença da Reduc.

De modo geral, os moradores de Duque de Caxias são contratados em regime de terceirização e ocupam os cargos de melhor remuneração, como funções de operação, serviços de limpeza e manutenção (Simões, 2015). Com isso, a renda efetiva e a situação real dos habitantes no município não correspondem ao que se mostra na Figura 5, sendo mais bem retratadas quando se analisa a renda média domiciliar (Figura 6).

Figura 6. Renda média domiciliar nos municípios da RMRJ (2010)

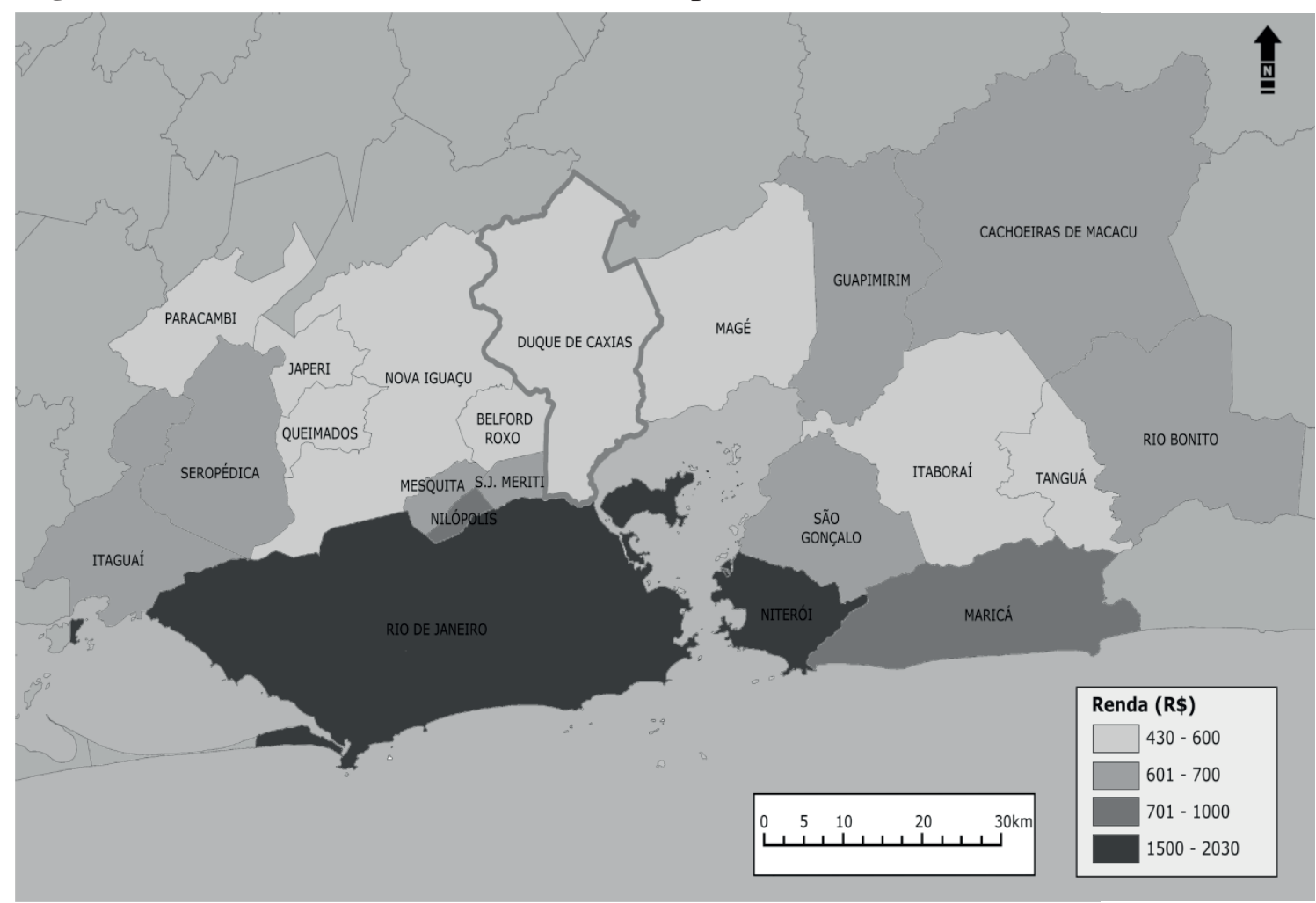

Fonte: Elaborado a partir de dados do IBGE (2010).

Nesse mapa, percebe-se que a situação de Duque de Caxias está piorando de forma significativa, com uma renda média domiciliar inferior à de municípios como Guapimirim, Nilópolis e São João de Meriti, cujas economias são muito menores. Dessa forma, a comparação entre os salários médios pagos e a renda média domiciliar nos leva a afirmar que há uma drenagem da riqueza produzida na cidade para outros municípios, especialmente para a capital, Rio de Janeiro, moradia dos funcionários de maior remuneração, sede da Petrobras e de suas empresas-satélite, além de local em que se processa a enorme movimentação bancária da empresa. 
A baixa renda média domiciliar dos habitantes de DC acaba por influenciar diretamente a qualidade de vida desfrutada pela população, incluindo o tipo de moradia dos cidadãos locais. Além do elevado número de habitações precárias, Caxias possui a maior população absoluta vivendo em favelas de toda a Baixada Fluminense e a segunda maior do estado, como se vê na Tabela 2.

Tabela 2. População residente total e em aglomerados subnormais em municípios selecionados da RMRJ (2010)

\begin{tabular}{|c|c|c|c|c|c|c|}
\hline \multirow{3}{*}{ Municípios } & \multicolumn{3}{|c|}{ População (2000) } & \multicolumn{3}{|c|}{ População (2010) } \\
\hline & \multirow[t]{2}{*}{$\begin{array}{l}\text { Habitantes } \\
\text { (Total) }\end{array}$} & \multicolumn{2}{|c|}{$\begin{array}{l}\text { Residentes em aglome- } \\
\text { rados subnormais }\end{array}$} & \multirow{2}{*}{$\begin{array}{l}\text { Habitantes } \\
\text { (Total) }\end{array}$} & \multicolumn{2}{|c|}{$\begin{array}{l}\text { Residentes em aglome- } \\
\text { rados subnormais }\end{array}$} \\
\hline & & Total & $\%$ & & Total & $\%$ \\
\hline Rio de Janeiro & 5.857 .904 & 1.095 .949 & $18,7 \%$ & 6.320 .446 & 1.393 .314 & $22,0 \%$ \\
\hline São João de Meriti & 449.476 & 11.875 & $2,6 \%$ & 458.673 & 47.322 & $10,3 \%$ \\
\hline Belford Roxo & 434.474 & 1.757 & $0,4 \%$ & 469.332 & 35.480 & $7,6 \%$ \\
\hline Duque de Caxias & 775.456 & 56.659 & $7,3 \%$ & 855.048 & 61.452 & $7,2 \%$ \\
\hline Queimados & 121.993 & 1.286 & $1,1 \%$ & 137.962 & 5.428 & $3,9 \%$ \\
\hline Japeri & 83.278 & 14 & $0,0 \%$ & 95.492 & 2.377 & $2,5 \%$ \\
\hline Nilópolis & 153.712 & 1.616 & $1,1 \%$ & 157.425 & 3.557 & $2,3 \%$ \\
\hline Nova Iguaçu & 920.599 & 5.667 & $0,6 \%$ & 796.257 & 9.541 & $1,2 \%$ \\
\hline Mesquita & - & - & - & 168.376 & 1.061 & $0,6 \%$ \\
\hline
\end{tabular}

Fonte: Elaborado a partir de dados do IBGE Cidades (2015).

A observação dessa tabela nos leva a concluir que os municípios da Baixada Fluminense com as maiores porcentagens de habitantes residindo em aglomerados subnormais são aqueles situados nas imediaçôes da Zona Norte da cidade do Rio de Janeiro, ou seja, São João de Meriti, Belford Roxo e Duque de Caxias. De acordo com Pierre Costa (2012), a proximidade com o núcleo da metrópole e a grande quantidade de terras disponíveis e situadas em áreas de baixo interesse especulativo - muitas delas públicas -, tais como margens de rios, mangues e brejos, são alguns dos fatores que fizeram com que DC se tornasse mais favelizada do que os demais municípios da Baixada.

$\mathrm{Na}$ Tabela 2, também se observa diminuição relativa do número de residentes em aglomerados subnormais em Caxias. Em 2000, 7,3\% da população total do município residia nesse tipo de habitação. Em 2010, o número passou a ser de 7,2\%. Apesar disso, pode-se afirmar que DC possui uma elevada proporção de habitantes vivendo em condições precárias, cuja qualidade de vida se mantém em níveis muito baixos. Portanto, se Caxias ocupa posição privilegiada no estado do Rio de Janeiro e na RMRJ quando se comparam os indicadores econômicos, a situação muda radicalmente quando se 
apresentam os dados sociais. No Gráfico 4, podemos observar o IDHM ${ }^{15}$ de alguns dos municípios da RMRJ, com Duque de Caxias ocupando a 12a colocação - em comparação com os demais municípios do estado, DC se encontra na nada honrosa 49a colocação, de um total de 92 municípios.

Gráfico 4. Índice de Desenvolvimento Humano Municipal (2010)

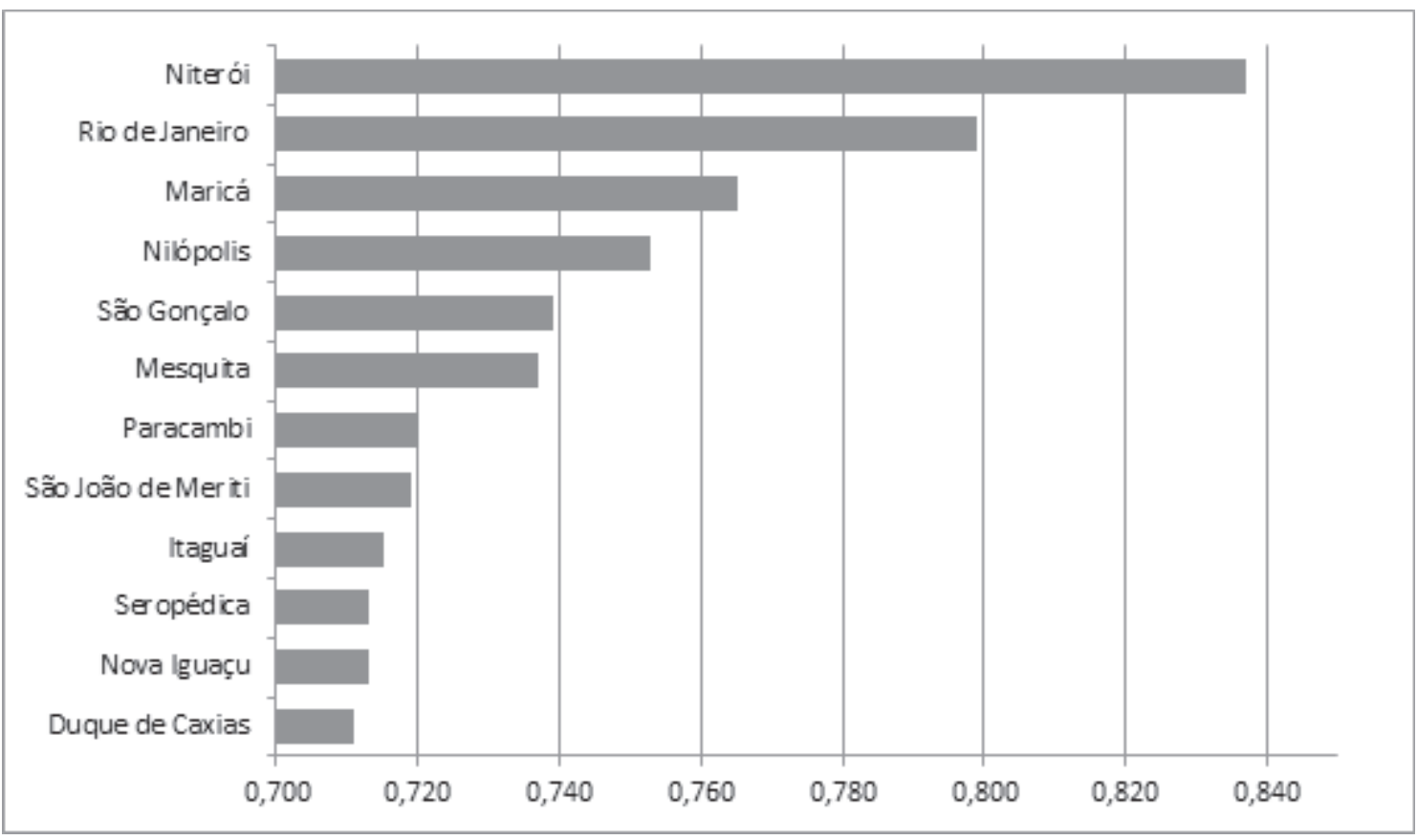

Fonte: Elaborado a partir de dados do PNUD (2013).

Portanto, esses indicadores socioeconômicos gerais do município denotam um forte contraste: por um lado, a elevada produção de riqueza local; por outro, a baixa renda média domiciliar e a péssima situação no ranking do IDH municipal. Contudo, esse dado ainda não reflete plenamente a realidade do município, já que representa uma média de indicadores das diversas localidades e bairros. Podemos realizar uma interpretação diferente de DC quando observamos a Figura 7, que apresenta as diferenças no IDH do interior dos municípios pertencentes à região metropolitana do Rio de Janeiro.

\footnotetext{
${ }^{15}$ O Índice de Desenvolvimento Humano Municipal (IDHM) utiliza cerca de dois mil indicadores de renda, educação e longevidade para estabelecer um parâmetro de acesso a direitos básicos de cidadania, como escola, saúde, saneamento, emprego e serviços públicos, o que, em tese, garante uma boa qualidade de vida. Por outro lado, a ausência ou deficiência desses serviços ou bens implica perda da qualidade de vida, o que se reflete em índices mais baixos.
} 
Figura 7. IDHM dos municípios da RMRJ (2010)

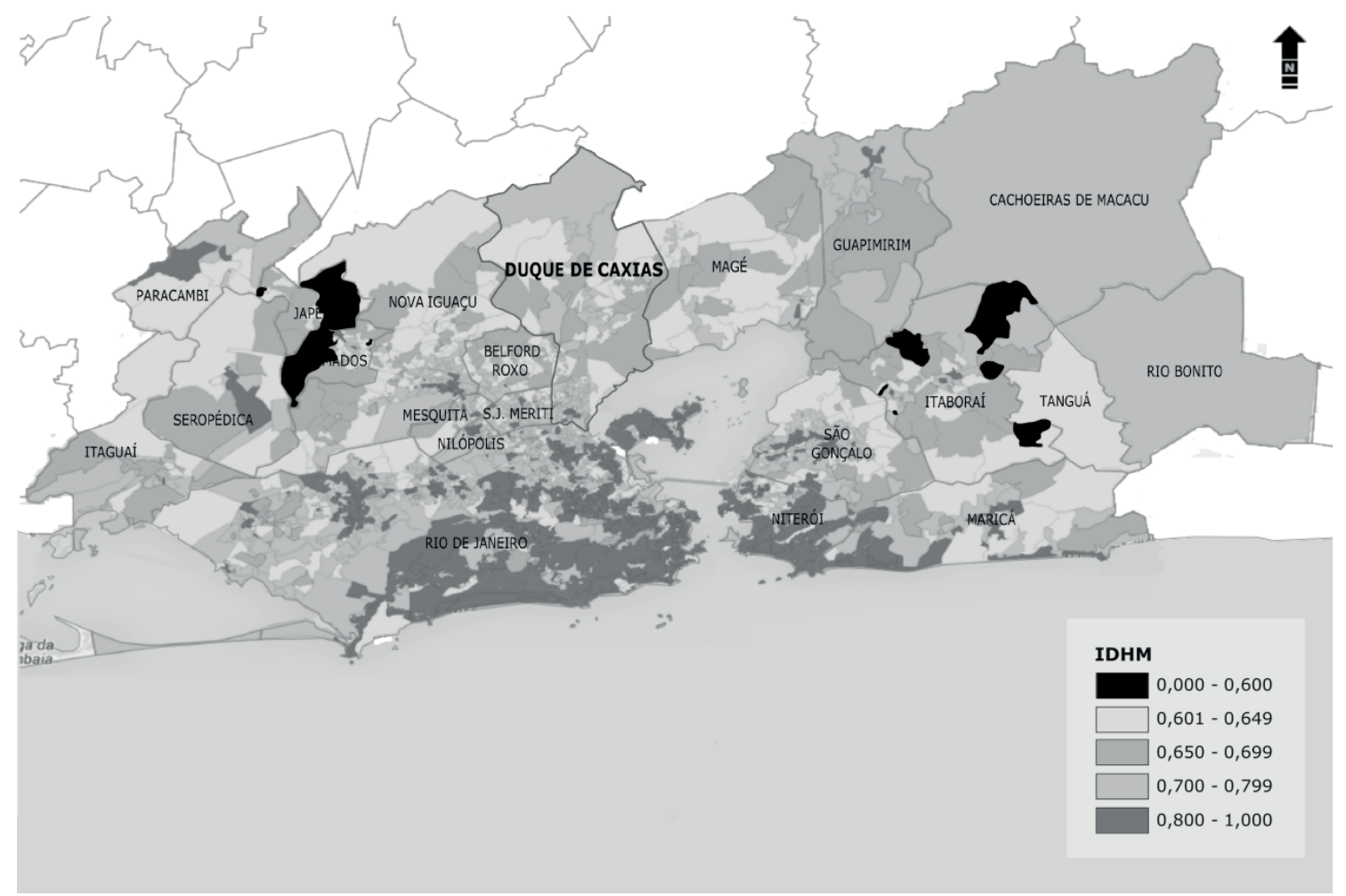

Fonte: Elaborado a partir de dados do PNUD (2013).

Dessa forma, conclui-se que, internamente, no município de DC há uma forte disparidade nos indicadores que medem a qualidade de vida, com predomínio de áreas precárias e muito precárias, embora também existam "ilhas" de prosperidade socioeconômica. Esse padrão, longe de ser exclusividade de Caxias, condiz com o que Mckenzie afirmou no início do século XX (1921): "A distribuição [...] da população [numa] grande cidade é determinada pelos interesses de forças econômicas que tendem a produzir estruturas similares em todas as grandes cidades" (1921, p. 147).

Às palavras escritas por Mckenzie, acrescentamos que esse processo não ocorre apenas nas grandes cidades, mas também na periferia, assim como em cidades de porte médio, como é o caso de Duque de Caxias. $\mathrm{O}$ autor defende que a população tende a se dividir em função de seu status econômico em áreas residenciais com valores diferenciados. Para ele, as disparidades de renda entre as famílias, causadas por diversas razões, estimulam a segregação da população em diferentes bairros. Para compreender o porquê de tais diferenças em Duque de Caxias, julgamos ser necessário revisitar, ainda que de forma breve, o surgimento do município e, inevitavelmente, da própria Baixada Fluminense. 


\title{
2. A gênese do espaço caxiense
}

\begin{abstract}
Quando, no dia 30 de agosto de 1993, a favela de Vigário Geral expunha ao mundo os 21 mortos da maior chacina cometida pela Polícia Militar no Rio de Janeiro, uma deputada federal lamentou, no rádio, a tragédia ocorrida naquela "favela da Baixada Fluminense" [sic]. Assim, o bairro, que, na verdade, pertence ao subúrbio carioca, foi incorporado à Baixada. Esse equívoco, por sua vez, revela o problema dos limites dessa região. $\mathrm{O}$ aspecto geográfico acaba se relacionando com o político e com o social na construção de fronteiras não muito precisas (Alves, 2003, p. 15).
\end{abstract}

De início, é importante frisar que não buscamos propor um conceito do que vêm a ser a Baixada da Guanabara e a Baixada Fluminense, nem lhes estabelecer limites definitivos. O propósito, aqui, é delimitá-las de uma forma mais apropriada no âmbito desta pesquisa, a partir de abordagens existentes, com o fim de justificar o recorte territorial escolhido.

\subsection{Discutindo a Baixada Fluminense}

É importante lembrar que a Baixada não existe oficialmente, pertencendo ao imaginário da geografia política e ao uso no cotidiano. À exceção da Secretaria Especial da Baixada Fluminense, criada e extinta no início dos anos 2000 (Simões, 2011), nenhum órgão público considerado para fins estatísticos ou de planejamento e intervenção estabeleceu uma delimitação oficial dessa unidade territorial. Em diversos trabalhos pesquisados, foram empregados conceitos variados, com a inclusão ou exclusão de alguns municípios de acordo com os critérios ou interesses em questão. Entretanto, mesmo sendo esse um conceito tão fluido, é possível apontar algum consenso a respeito.

Os municípios de Duque de Caxias e Nova Iguaçu aparecem em todas as definições de Baixada, sendo considerados, de forma unânime, os núcleos dessa região. Há consenso também de que pertencem à Baixada os municípios de Belford Roxo, São João de Meriti, Nilópolis, Mesquita, Queimados e Japeri, considerados satélites imediatos dos municípios-núcleo. Assim, as discordâncias giram em torno da inclusão ou não dos municípios mais afastados do núcleo-base: Magé, Guapimirim, Itaguaí, Seropédica e Paracambi.

De acordo com Simões (2015), o termo Baixada Fluminense (BF) não era utilizado pelos moradores, estudiosos, técnicos e membros do governo até o final do século XIX. O autor acrescenta que a expressão provém da geografia física, surgindo no momento em que as recém-criadas comissões de saneamento almejavam efetuar intervenções na região, com o objetivo de reduzir as inundações e as frequentes epidemias que as seguiam.

Do ponto de vista geográfico, a BF é uma planície que se estende paralelamente à costa em corredor entre a serra do Mar e o oceano (Beloch, 1986; Torres, 2008). Portanto, de acordo com esse critério, inclui terras desde Itaguaí até a divisa com o Espírito Santo. Ou seja, num sentido geomor- 


\section{Situando Duque de Caxias no contexto metropolitano da Baixada Fluminense}

fológico amplo, sua área abrange quase integralmente o litoral do estado do Rio de Janeiro (Oliveira, 2004; Simōes, 2011). Por isso, aqui esse recorte espacial será denominado Baixada Estadual.

No entanto, na década de 1930, Hildebrando de Góes propõe uma diferenciação das áreas dentro dessa Baixada Estadual, criando uma classificação fisiográfica que passou a ser usada regularmente por diversos geógrafos. Nela, Duque de Caxias se situaria na Baixada da Guanabara, que incluiria apenas as terras do entorno da Baía de Guanabara, indo de Guapimirim a Itaguaí (Figura 8).

Figura 8. Baixada da Guanabara e Região Metropolitana do Rio de Janeiro

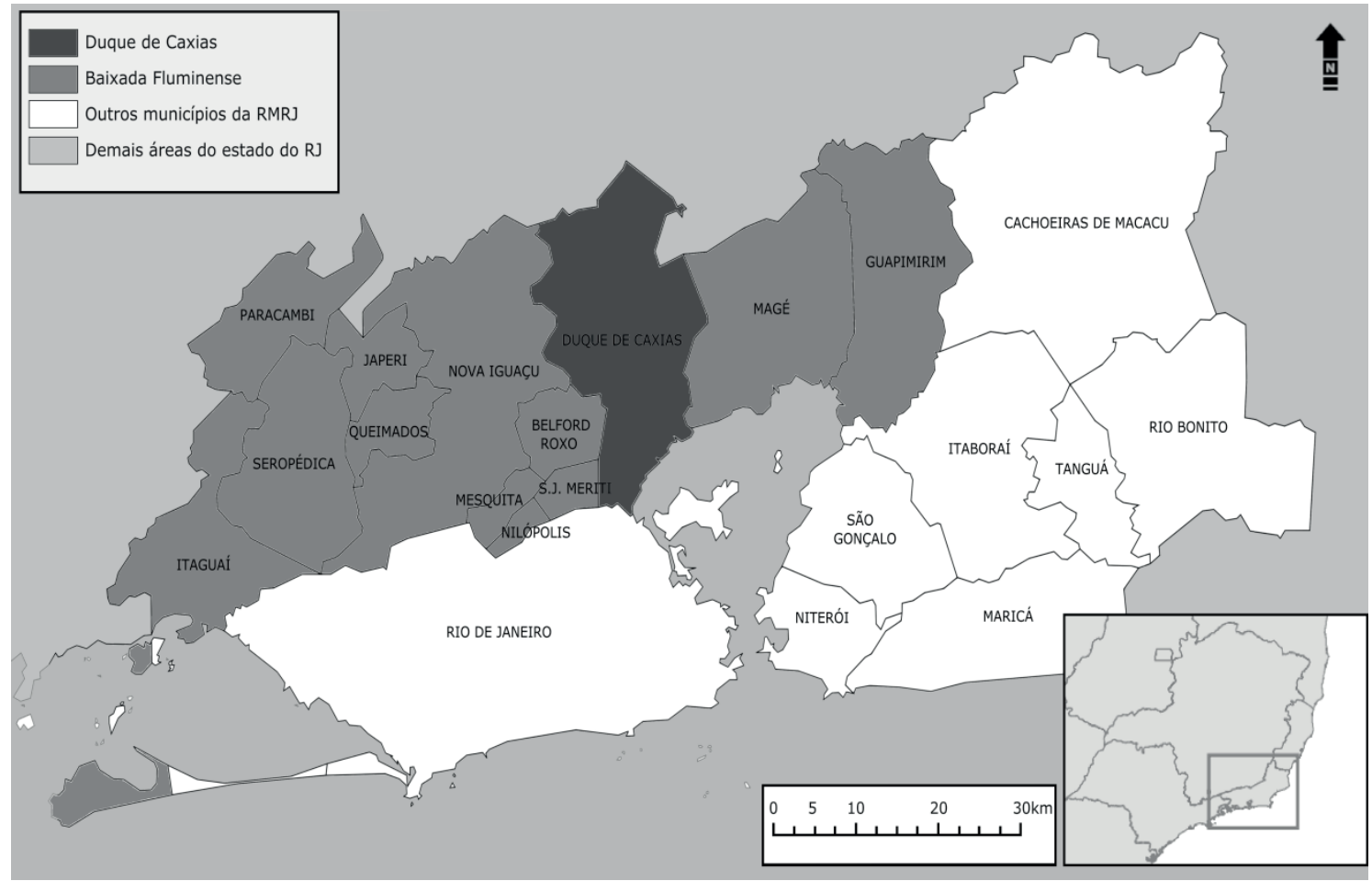

Fonte: Leandro Silveira.

O termo, porém, adquire sua acepção atual entre as décadas de 1940 e 1950, com uma conotação fortemente pejorativa. Isso ocorre porque esse é o período em que a imprensa carioca passa a retratar a regiāo como um lugar violento e miserável, em que faltam bens e serviços públicos. Por isso, a definição se consolida e, na década de 1960, já está fortemente popularizada. Entretanto, os limites permanecem difusos até hoje, pois a inclusão ou exclusão de áreas ${ }^{16}$ da região depende dos interesses envolvidos.

\footnotetext{
${ }^{16}$ Inserção nossa.
} 
Para Simões (2011), no contexto da divisão fisiográfica já apontada como Baixada da Guanabara (Figura 8), é possível efetuar uma subdivisão, segmentando o que o autor denomina como Baixada Núcleo e Baixada Ampliada. A Baixada Ampliada corresponderia ao recorte espacial apresentado como Baixada da Guanabara na Figura 8. Por sua vez, a área em que a população local se identifica plenamente com o pertencimento à Baixada Fluminense é chamada de Baixada Núcleo, formada pelo desmembramento dos antigos municípios de Iguassú e Estrella, hoje fracionados em nove municípios distintos (Figura 9).

Figura 9. Baixada Fluminense Núcleo e Baixada Ampliada

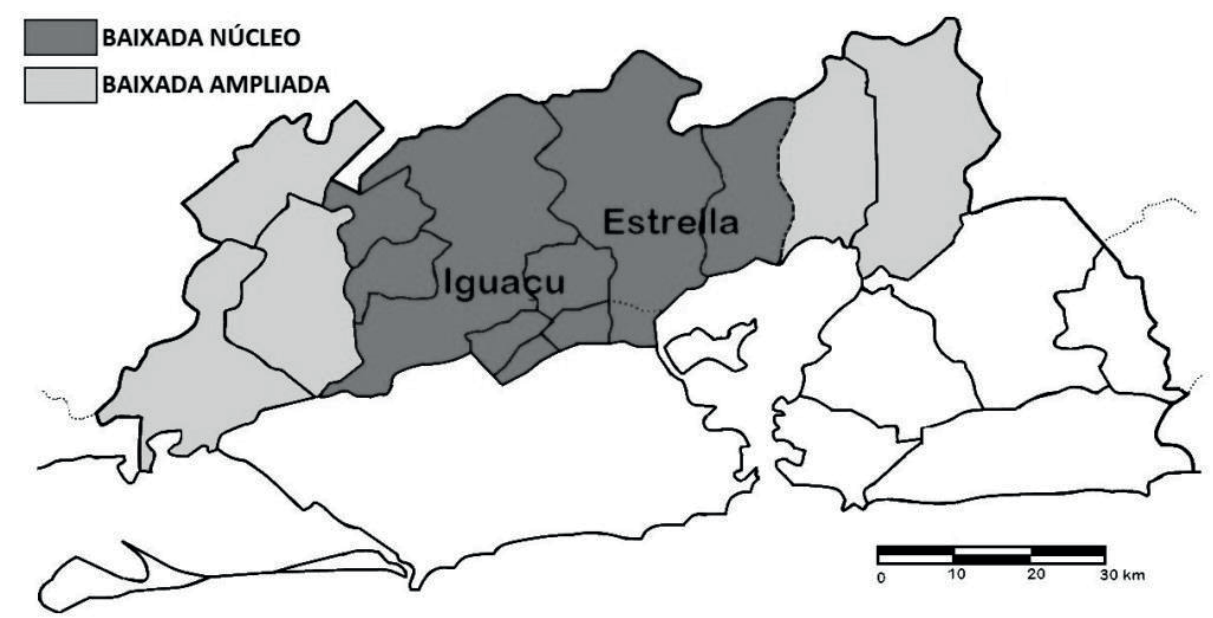

Fonte: Adaptado de Simões (2011).

Ao mesmo tempo, Simões (2004) afirma que, geopoliticamente, o termo Baixada Fluminense é cada vez mais identificado com a área original do antigo município de Iguaçu, ${ }^{17}$ que se formou nas terras da sesmaria de mesmo nome e passou por um processo de desmembramento (Figura 10) ao longo do século XX.

\footnotetext{
${ }^{17}$ Nome original das terras do atual município de Nova Iguaçu, cuja primeira grafia era Iguassú, originada da palavra indígena Igoassú. Em 1943, quando tem início o processo de emancipação de seus distritos, o município já se chamava Nova Iguaçu.
} 


\section{Situando Duque de Caxias no contexto metropolitano da Baixada Fluminense}

Figura 10. Desmembramento do antigo município de Nova Iguaçu

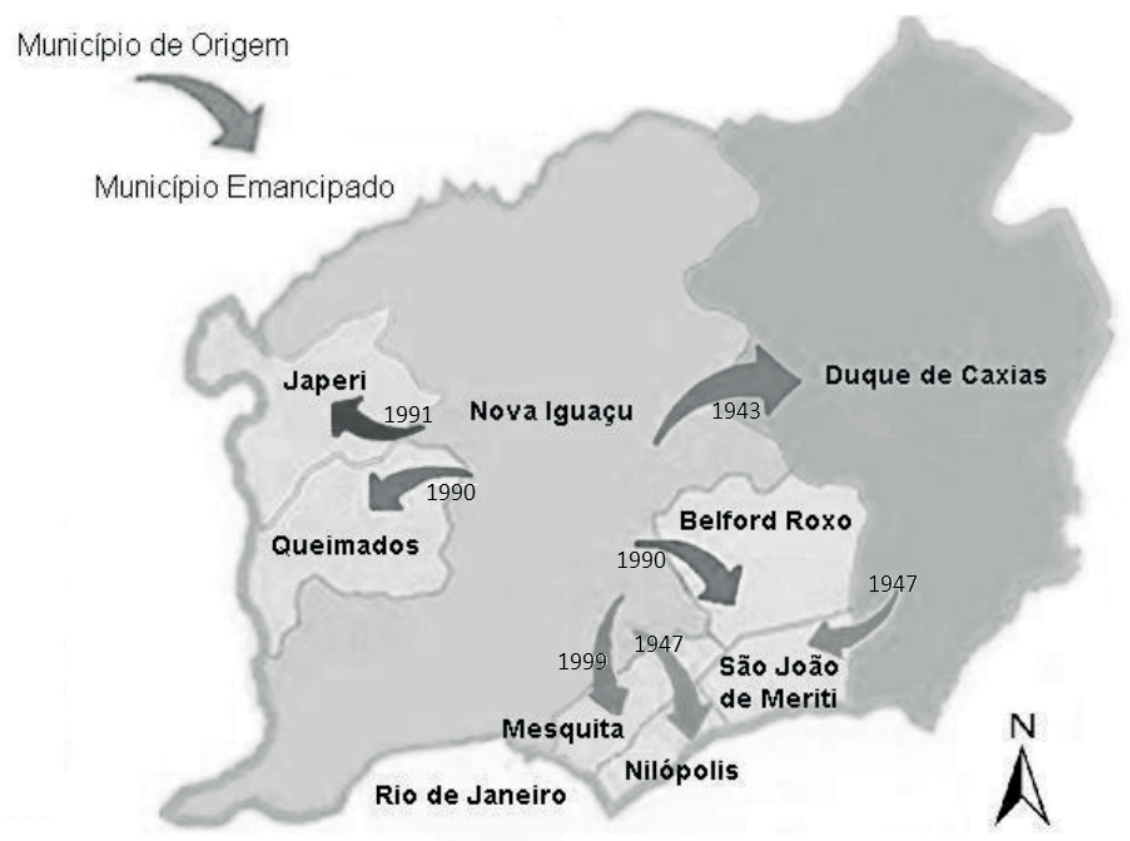

Fonte: Adaptado de Tenreiro (2012, p. 25).

Assim, com base em critérios como grau de urbanização, violência e densidade populacional, a Fundação para o Desenvolvimento da Região Metropolitana do Rio de Janeiro (Fundrem) restringiu a Baixada a oito municípios, sendo dois núcleos - Nova Iguaçu e Duque de Caxias - e seis "satélites" - Belford Roxo, São João de Meriti, Nilópolis, Mesquita, Queimados e Japeri (Costa, 2012). Tal recorte é utilizado com frequência, como afirma Israel Beloch:

[...] [É] comum [...] designar-se como Baixada Fluminense apenas a porção da Baixada da Guanabara mais próxima, e, portanto, mais intimamente vinculada ao antigo Distrito Federal - os municípios de Nova Iguaçu, Duque de Caxias, Nilópolis e São João de Meriti, detentores de uma configuração física, econômica e social que lhes propiciou um dos maiores crescimentos demográficos do país e os tornou alojamento de grandes massas populacionais, constituídas quase exclusivamente de trabalhadores, em boa parte subempregados (Beloch, 1986. p. 16).

Dessa forma, podemos afirmar que a definição mais recorrente é a que recorre a critérios socioeconômicos, incluindo um grupo de municípios, em sua maioria, recém-emancipados, com infraestrutura precária e ocupados por uma população de baixa renda. Apesar de possuir $26 \%$ da população do estado do Rio de Janeiro, a Baixada Fluminense detém apenas 10\% do total da renda familiar (IBGE, 2015), com rendimento médio por habitante em torno de um salário mínimo. Mais de 15\% 
da população local recebe menos de meio salário mínimo; 67\% recebem entre meio e dois salários mínimos; e apenas 18,6\% recebem mais de dois salários mínimos (IBGE, 2015).

Neste artigo, não nos interessa delimitar, com rigidez extrema, o recorte a ser utilizado. Ao citarmos a expressão Baixada Fluminense, consideraremos, na maior parte das vezes, a delimitação apontada por Simões (2011) como Baixada Núcleo. Ao mesmo tempo, preferimos manter os limites fluidos para, quando necessário, utilizarmos o termo para nos referir à Baixada Ampliada. Em nenhum momento, porém, incluiremos qualquer município que esteja fora dos limites apontados pela Figura 8.

\subsection{A ocupação inicial das terras caxienses}

A ocupação das terras em que se encontra atualmente o município de Duque de Caxias ocorreu ao mesmo tempo que surgia a cidade do Rio de Janeiro, ou seja, logo após a vitória dos portugueses sobre os franceses e os indígenas nativos, ${ }^{18}$ depois de dois anos de combate (Cavalcanti, 2010). A partir de então, a Coroa portuguesa buscou colonizar e cultivar as terras às margens da Baía de Guanabara, instalando o regime de sesmarias. ${ }^{19}$ Segundo Lima (2010, p. 139), além da função estratégica de defesa, os portugueses viam potencial agrícola na área para abastecer a cidade recém-fundada.

A primeira sesmaria foi doada pela Coroa portuguesa ao ouvidor-mor Cristóvão Monteiro ${ }^{20} \mathrm{em}$ 1565, dando início ao povoamento da região. Às margens do rio Iguaçu, essas terras deram origem à Fazenda Iguaçu, ${ }^{21}$ que se tornou a primeira propriedade lusitana no território atualmente chamado de Baixada Fluminense. O local foi ocupado com a cultura da cana-de-açúcar e a produção de alimentos para a cidade do Rio de Janeiro (Lamego, 1964; Simões, 2015). Posteriormente, a fazenda foi

\footnotetext{
${ }^{18}$ Enquanto invadiam e ocupavam o Rio de Janeiro, os franceses se aproximaram e fizeram alianças com os índios tamoios, numa estratégia que lhes permitisse ter mais chances de controlar o território já pertencente aos portugueses. Contudo, a aliança feita pelos indígenas viria a se revelar trágica para eles, já que o fim da invasão, com a vitória dos portugueses, teve dois desdobramentos: "o ódio dos portugueses aos índios, então aliados dos franceses, que levou praticamente ao aniquilamento destes, e a decisão de dividir a região em sesmarias, para promover a ocupação populacional e evitar novas invasões" (Cardoso, 2010, p. 27).

${ }^{19}$ Ver Lamego (1964), Abreu (2005) e Cavalcanti (2010).

${ }^{20}$ Em agradecimento à sua atuação na luta contra os franceses, em 5 de setembro de 1565, Estácio de Sá - primeiro governador-geral da capitania do Rio de Janeiro - doou uma grande faixa de terra a Cristóvão Monteiro em ambas as margens do rio Iguaçu (Nogueira, 2008). Cavaleiro fidalgo da Casa Real Portuguesa, Monteiro construiu a fazenda de Igoassu, tornando-a "uma área de plantio de alimentos de subsistência e de cana-de-açúcar" (Lima, 2010, p. 140).

${ }^{21}$ Originalmente, a Fazenda Iguaçu fez parte da sesmaria Igoassu, que correspondia à maior porção da região, chamada de Baixada Fluminense, ou Baixada da Guanabara, como era conhecida nos tempos coloniais. Dado pelos povos originários, o "termo Igoassu faz referência aos rios e pântanos, significando água grande ou muita água" (Lima, 2010, p. 140, grifo do autor) e foi usado para batizar a unidade administrativa que compreendia quase todo o território baixadense delimitado ao longo do século XIX.
} 


\section{Situando Duque de Caxias no contexto metropolitano da Baixada Fluminense}

adquirida pela Ordem de São Bento ${ }^{22}$ e tornou-se um engenho açucareiro, com produção de açúcar, aguardente e garapa, passando a ser chamada de Fazenda São Bento ou São Bento do Iguaçu (Figura 11). É considerada a mais antiga do atual município de Duque de Caxias e se mostrou fundamental no início do desenvolvimento econômico e populacional da região.

Figura 11. Fazenda São Bento (década de 1910)

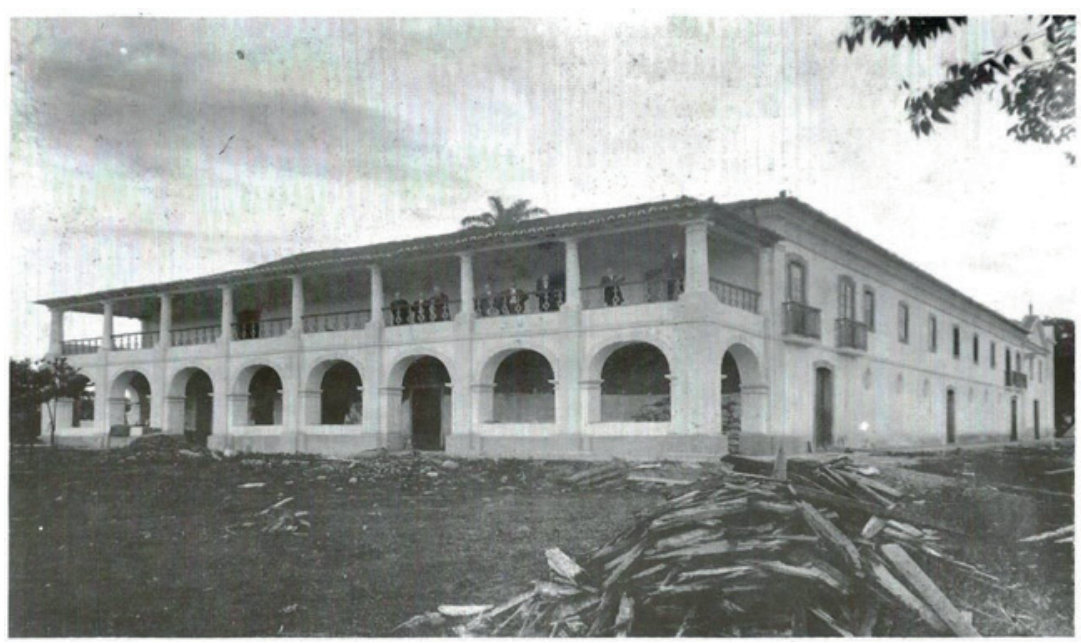

Fonte: Nogueira (2008, p. 57).

Assim, pode-se afirmar que as histórias de Caxias e da Baixada Fluminense estão intimamente conectadas à da metrópole Rio de Janeiro e à sua dinâmica econômica. Afinal, situada às margens da Baía de Guanabara, o desenvolvimento da BF esteve ligado à extensa rede hidrográfica que a cortava. Através dos rios, "realizava-se o escoamento da produção local e estabeleciam-se os elos entre o interior e o litoral, favorecendo a ocupação das cercanias da Baía pelo interior serrano" (Nogueira, 2008, p. 54).

Apesar de a atividade econômica que incentivou a ocupação inicial da região ter sido o cultivo da cana-de-açúcar, a retirada de lenha e a produção de outros alimentos, como milho, feijão, mandioca e arroz, também serviram para abastecer a cidade do Rio de Janeiro (Nogueira, 2008). É fato que a Baixada Fluminense apresenta grande dependência econômica em relação ao Rio de Janeiro, e os grandes fluxos pendulares em direção ao núcleo da metrópole comprovam essa realidade.

\footnotetext{
${ }^{22}$ Em 12 de outubro de 1591, a Ordem de São Bento comprou parte dessas terras. Alguns anos depois, a viúva e o sogro de Cristóvão Monteiro doaram outra porção da antiga sesmaria Iguaçu aos beneditinos. Em 1613, o local recebeu a instalação de um moderno engenho, tornando a fazenda por muito tempo "responsável pela conquista, povoamento e prosperidade da regiāo" (Moraes, 1990, p.73). Esteve sob a administração dos beneditinos até 1920, quando foi desapropriada pela empresa Pró-Melhoramentos para fins de saneamento e colonização.
} 
Com efeito, tal situação não era tão diferente naquela época. O fato é que tanto a ocupação quanto o desenvolvimento econômico da região sempre foram determinados pela atual metrópole carioca (Lamego, 1964).

Os primeiros aglomerados surgiram no entorno de igrejas, como a de São Bento, por volta de 1596, e a de Nossa Senhora do Pilar, em 1612 (Simões, 2015). Ao longo do século XVII, a população da Baixada se manteve reduzida e concentrada principalmente nos engenhos, uma vez que a área era sede, basicamente, de culturas canavieiras, produção de açúcar e aguardente.

No século seguinte, a Baixada Fluminense cresceu de forma expressiva, e sua relação com a urbe carioca se estreitou ainda mais pelos caminhos que ligavam a região das Minas Gerais ao litoral. Com o deslocamento do eixo econômico do Nordeste para o Centro-Sul no século XVIII, surgiu, então, a necessidade de escoar o ouro e abastecer a província mineira. ${ }^{23} \mathrm{O}$ tráfego cresceu muito rápido em 1704, após a abertura do Caminho Novo, ${ }^{24}$ que passou a transpor a serra dos Órgãos (Pinheiro, 2010). Porém, como os "caminhos de terra firme" (Torres, 2008, p.195) eram poucos, precários e perigosos, o transporte fluvial se tornou a principal alternativa para que o trânsito de mercadorias se desenvolvesse. O transporte era feito pelos rios, prolongando-se por via marítima através da Baía de Guanabara até alcançar o porto do Rio de Janeiro. Contando com numerosos rios, a Baixada Fluminense se transformou num ponto de união entre o litoral e os caminhos que subiam a serra em direção ao interior.

Em pouco tempo, a Baixada passou a ter importância estratégica, tornando-se ponto obrigatório de passagem daqueles que se dirigiam à região das minas ou de lá regressavam (Lamego, 1964; Nogueira, 2008), principalmente por conta de seus rios, mas também pelas estradas que foram abertas através das serras. Tais caminhos (Figura 12), que partiam de portos fluviais como Pilar e Estrela, tornaram-se pontos de aglutinação de pessoas e atividades econômicas, o que resultou no surgimento dos primeiros núcleos urbanos (Simões, 2015). E, mesmo após a decadência da mineração, a região ainda se manteve como ponto de parada e abastecimento de tropeiros, assim como local de passagem de mercadorias (Beloch, 1986, p. 17). Por essa razão, o desenvolvimento das áreas no entorno da Baía de Guanabara foi notável desse período até o século XIX.

\footnotetext{
${ }^{23}$ A partir de então, a cidade do Rio de Janeiro ganhou novas funçôes e atividades, tornando-se capital da colônia em 1763 e apresentando forte dependência da rede de portos fluviais e caminhos que atravessavam a Baixada Fluminense.

${ }^{24} \mathrm{O}$ Caminho Novo do Pilar, aberto em função das necessidades oriundas da mineração, entre elas um caminho rápido, econômico e seguro que ligasse o Rio de Janeiro à região das Minas Gerais, "intensificou as relaçôes daquela cidade com os portos Estrela, Pilar e Iguaçu” (Nogueira, 2008, p. 55).
} 


\section{Situando Duque de Caxias no contexto metropolitano da Baixada Fluminense}

Figura 12. Caminhos e estradas da Baixada no início do século XIX

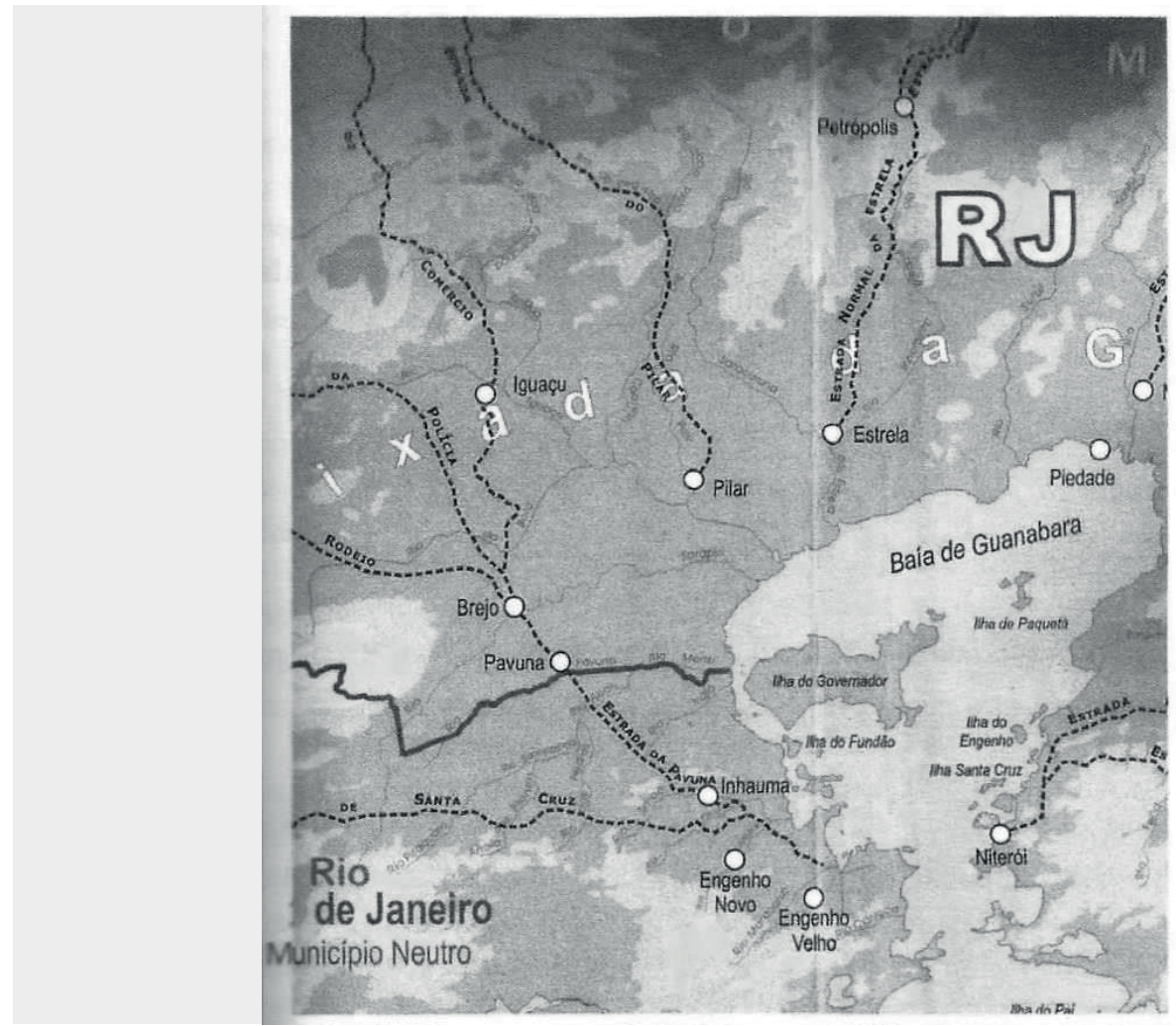

Fonte: Brame apud Simões (2015, p. 25).

No início do século XIX, a expansão da produção de café pelo Vale do Paraíba gerou novo impulso ao fluxo pelos caminhos localizados na BF, promovendo o crescimento populacional em seu entorno e, especialmente, nas imediações dos portos fluviais. Um novo aumento demográfico ocorreria com a chegada da família real e da Corte portuguesa em 1808, o que aumentou ainda mais o fluxo comercial pelos portos fluviais da Baixada (Lamego, 1964; Nogueira, 2008; Simóes, 2015). Entretanto, junto com o século XIX, chegaram também as primeiras ferrovias ${ }^{25}$ (Figura 13), que transformaram profundamente a organização regional, alterando o eixo de ocupação e levando os portos fluviais e seus respectivos núcleos à ruína. ${ }^{26}$

\footnotetext{
${ }^{25}$ A primeira ferrovia do Brasil foi instalada em 1854, em Mauá, parte da atual cidade de Magé. Em seguida, surgiu a Estrada de Ferro D. Pedro II (1858), que, por sua vez, cortava todo o território iguaçuano e, posteriormente, passaria a se chamar Estrada de Ferro Central do Brasil.

${ }^{26} \mathrm{O}$ novo meio de transporte promoveu o abandono dos portos fluviais e dos núcleos que dependiam deles, como a Vila de Estrela, cujos territórios, atualmente, fazem parte de Duque de Caxias, Magé e Petrópolis. Pouco antes da instalação da estrada de ferro, o porto de Estrela havia sido considerado um dos mais impor-
} 
Figura 13. Município de Duque de Caxias e ferrovias no fim do século XIX

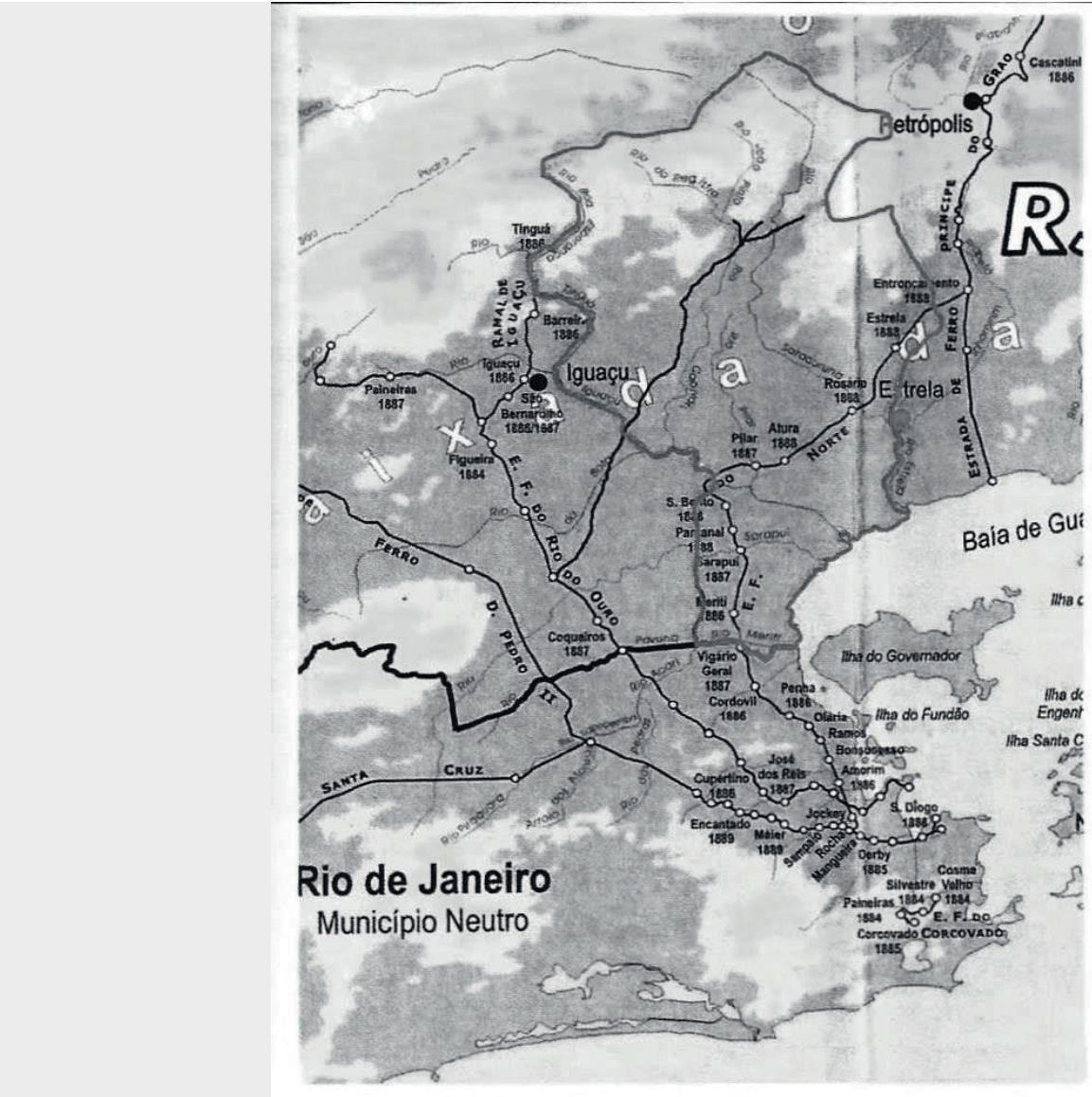

Fonte: Brame apud Simōes (2015, p. 27).

Portanto, as quatro primeiras ferrovias fluminenses desencadearam um forte "processo de desarticulação no transporte fluviomarítimo, até então o principal sistema de transporte de passageiros e mercadorias entre o Vale do Paraíba, a Serra do Mar, a Baixada da Guanabara e a Serra do Mar" (Brame, 2010, p. 371). Segundo Beloch (1986), a maior eficiência do transporte ferroviário

[...] provocou a rápida desativação das vias fluviais. Os rios, utilizados cada vez com menor intensidade, foram sendo assoreados e obstruídos, em decorrência do desordenado desmatamento verificado no período anterior. Cedo começaram a ocorrer inundações e a região se viu pontilhada por charcos insalubres [...]. A

tantes do Brasil, já que era "um dos poucos que podia receber embarcações maiores e o único a contar com embarcações a vapor” (Moraes, 1990, p. 83). 
evasão dos proprietários de terras e o despovoamento provocaram vertiginoso declínio do atual território caxiense (p. 20).

Nas margens dos rios Meriti, Iguaçu e Sarapuí, cada vez mais assoreados, formavam-se brejos imensos, pântanos perigosos e mangues poluídos, cujas águas paradas se tornaram focos do surgimento de mosquitos e de malária (Torres, 2008). Os surtos da doença foram tão graves que, em cerca de cem anos, entre 1795 e 1880, a população de Duque de Caxias diminuiu de 17.022 habitantes para somente quatrocentas pessoas (Prado, 2000). As outrora salubres e cada vez mais povoadas terras tornaram-se mangues praticamente inabitáveis, e as epidemias frequentes levaram os senhores de engenho a abandonar suas propriedades, fugindo para lugares mais seguros.

Moraes (1990) aponta que o fluxo comercial passou a acompanhar a estrada de ferro, e os tropeiros e viajantes deixaram de circular pelo caminho tradicional. Além disso, o iminente fim da escravidão fez com que os escravos abandonassem as fazendas e os engenhos de cana. Para a agricultura da região, baseada no cultivo da cana-de-açúcar, foi um verdadeiro desastre. Por conta disso, a abolição da escravatura, em 1888, representou outro duro golpe para a regiāo. Afinal, a Baixada via-se privada de mão de obra para executar "as tarefas agrícolas e [as obras $]^{27}$ de infraestrutura que mantinham a salubridade local” (Torres, 2008, p. 196).

Em 1891, o município de Estrela foi extinto e o norte de Duque de Caxias ${ }^{28}$ voltou a fazer parte do município de Iguassú. Chamada, à época, de Merity, a área do atual $1^{\circ}$ Distrito de DC era pouco importante, representando apenas um ponto de escoamento de poucos produtos, dentre os quais lenha e carvão vegetal (Nogueira, 2008). Ironicamente, a futura recuperação e o desenvolvimento econômico de Merity aconteceriam com a criação de outra ferrovia: a "The Rio de Janeiro Northern Railway".

\section{Caxias e a Estrada de Ferro Leopoldina: fim do ocaso ou início da desordem?}

Se as primeiras estradas de ferro deram início à decadência de algumas áreas da Baixada Fluminense, outra ferrovia foi responsável pelo desenvolvimento do futuro núcleo do município de Duque de Caxias. Isso ocorreu com a criação, em 1886, da Estrada de Ferro Leopoldina, então chamada de "The Rio de Janeiro Northern Railway". Seu traçado passou a ligar a cidade do Rio de Janeiro à Vila de Merity, ${ }^{29}$ área que corresponde ao atual centro de Duque de Caxias. Porém, enquanto o Rio de

\footnotetext{
${ }^{27}$ Inserção nossa.

${ }^{28}$ Área que corresponde à maior parte do que, atualmente, abrange os distritos de Imbariê $\left(3^{\circ}\right)$ e Xerém $\left(4^{\circ}\right)$.

${ }^{29} \mathrm{O}$ novo caminho criado pela ferrovia modificou por completo as relaçóes comerciais e a ocupação do solo. Foi o início do processo de surgimento de vilas e povoados que se organizaram em torno das estações ferroviárias, origem de muitos bairros de nossas atuais cidades. Segundo as palavras de Torres, "sob a égide da maria-fumaça, de silvo estridente e penacho de fumo negro, tudo se modificou. A ferrovia [...] ditava novos traçados
} 
Janeiro se modernizava, ${ }^{30}$ Merity se encontrava no mais absoluto abandono nesse final de século XIX, com uma população de modestos quatrocentos habitantes e sem qualquer perspectiva de uso urbano (Costa, 2012).

Além disso, os aterros feitos para a obra agravaram a já péssima situação de drenagem na localidade. Por isso, apesar do fôlego econômico trazido pela nova ferrovia, o impacto inicial no povoamento não foi grande, pois a região continuaria a sofrer com a falta de saneamento por várias décadas, o que limitava o seu progresso. Com efeito, apesar de as ferrovias já possuírem estações nos atuais municípios de São João de Meriti, Nilópolis e Duque de Caxias desde o século XIX, sua ocupação urbana só se efetivou nas primeiras décadas do século XX - quando a região foi parcialmente drenada, como uma espécie de continuação da reforma sanitária iniciada na cidade do Rio de Janeiro, permitindo a instalação dos primeiros loteamentos urbanos.

Entretanto, as políticas públicas de saneamento eram marcadas por falta de efetividade e descontinuidade de açôes. ${ }^{31}$ Somente no Governo Nilo Peçanha (1909-1910), foram realizadas as primeiras ações consistentes ${ }^{32}$ para reduzir os problemas de saneamento na Baixada, ao se efetuarem obras de drenagem na parte noroeste da região. Enquanto governou o Rio de Janeiro (1914-1917),

nos caminhos, fazendo surgir à volta de suas estaçôes, povoados que se transformariam em populosas cidades. Quando a ferrovia atinge o vale de Meriti, a região começa a sofrer os efeitos da expansão urbana da cidade do Rio de Janeiro. Com a inauguração da "The Rio de Janeiro Northern Railway", em 23 de abril de 1886, ficamos definitivamente ligados ao antigo Distrito Federal. Era o progresso que novamente se avizinhava” (Torres, 2008, p. 196).

${ }^{30}$ Nesse mesmo período, agora capital federal da recém-proclamada República, o Rio de Janeiro promove uma transformação radical de sua forma urbana. Por meio de uma série de reformas, tem início a modernização da cidade, focada principalmente na área central. De acordo com Augusto Pinheiro (2010, p. 34), "a área central [da cidade do Rio de Janeiro] encontrava-se decadente, apinhada de cortiços e cabeças de porco, habitada por gente na mais extrema pobreza e assolada por epidemias que ameaçavam atingir toda a cidade". Entre as consequências sociais dessas reformas, estão a consolidação de uma estrutura espacial estratificada na cidade, que se disseminaria, no futuro, por Duque de Caxias e pelos outros municípios da Baixada Fluminense mais próximos à capital.

${ }^{31}$ Beloch (1986, p. 21) afirma que ninguém acreditava em saneamento na Baixada, pois "o problema do saneamento das terras da imensa planura fluminense, que circunda a capital da República, estava desmoralizado no seio da opinião pública". O autor aponta ainda que os fracassos nas políticas de saneamento vinham desde 1893, e que "cem mil contos desperdiçaram-se num esforço improfícuo e quase sem resultado até 1930" (Beloch, 1986, p. 21).

32 De acordo com Lucia Silva (2015), a Comissão Federal de 1910, instituída por Nilo Peçanha, em sua rápida passagem pela presidência da república, teve o mérito de consolidar como consenso todas as discussões travadas nas duas primeiras comissões estaduais e serviria de referência aos trabalhos das anteriores. Segundo a autora, "a comissão federal organizou as utopias do momento e tornara inconteste a ideia de saneamento como instrumento civilizatório, agente de modernização e como suporte imprescindível à agricultura. Desta forma, a Baixada adentrava a década de 1930 com a imagem de terra de promissão, desde que saneada" (Silva, 2015, pp. 3-4). 


\section{Situando Duque de Caxias no contexto metropolitano da Baixada Fluminense}

Peçanha continuou a promover outras melhorias no saneamento e acesso à água potável ${ }^{33}$ (Figura 14). Na presidência de Delfim Moreira (1918-1919), a criação do Serviço de Profilaxia Rural representou mais um passo para o controle das endemias na BF (Torres, 2008). Mas, apesar disso, o local continuava a ser um grave foco de malária.

Figura 14. Visita de Nilo Peçanha à estação de Merity (1916)

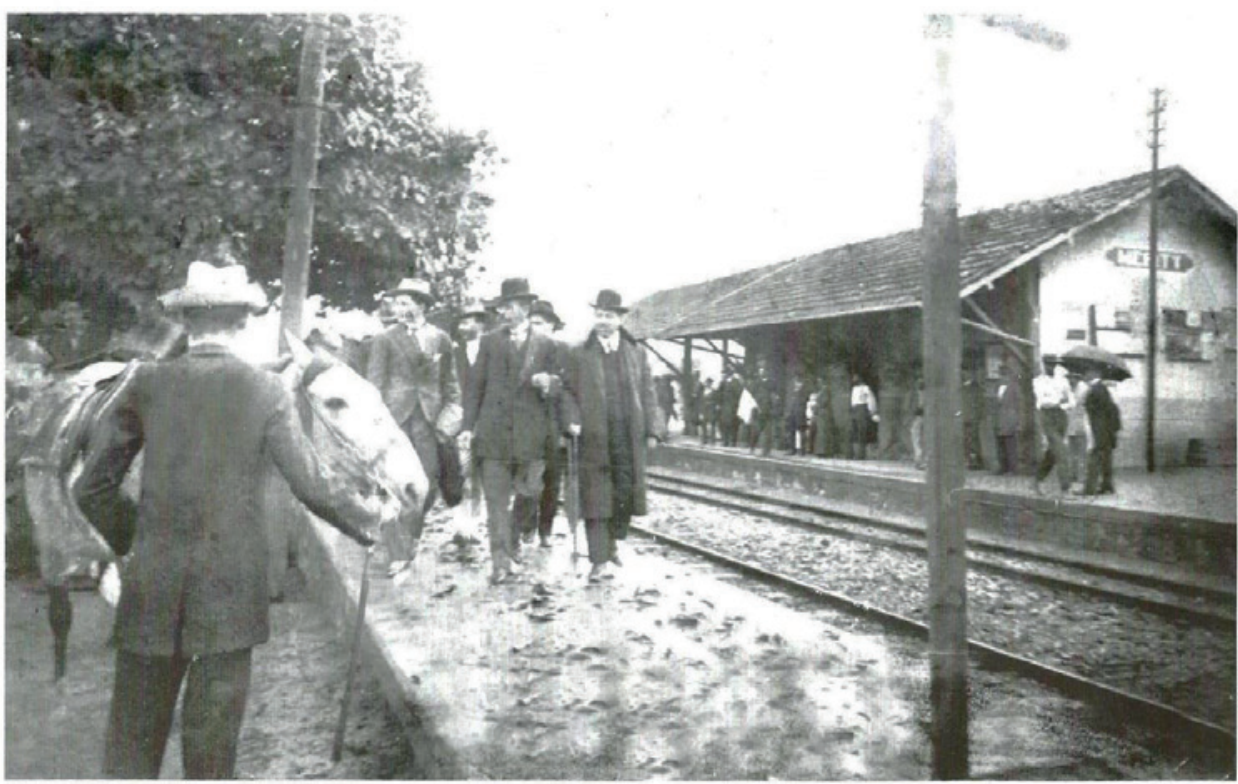

Fonte: Nogueira (2008, p. 63).

Já no governo de Getulio Vargas, os focos de origem da malária foram diretamente combatidos quando "foi instaurado um programa de abertura de canais, dragagem e retificação dos grandes rios que fez com que os pântanos desaparecessem"34 (Cardoso, 2010, pp. 28-9). Porém, Elmo Amador

\footnotetext{
${ }^{33}$ Em matéria do jornal O Municipal (2005), conta-se que, certa vez, de passagem por Merity rumo a Petrópolis, o presidente Nilo Peçanha ficou chocado com a correria de mulheres e crianças em direção ao "suspiro" da locomotiva, onde tentavam aproveitar o excesso de vapor, transformando-o em água potável. Ao saber que o local não dispunha de água potável, Nilo Peçanha determinou que fosse construído um ramal, a partir da rede de água que abastecia Vigário Geral, instalando duas bicas próximas à estação ferroviária, sendo uma na esquina da rua Joaquim Lopes de Macedo com a avenida Plínio Casado, e uma segunda, na esquina da rua Pinto Soares com a então estrada Rio-Petrópolis (O Municipal, 2005, p. 5).

${ }^{34}$ A partir de 1936, a criação do Serviço Nacional de Malária e da Diretoria de Saneamento da Baixada Fluminense permitiu um trabalho mais específico, com as seguintes açôes: desobstrução dos rios através da limpeza e retificação dos leitos, reabertura de canaletas de drenagem e irrigação, identificação dos rios dissimulados pela vegetação, mapeamento geral da região e criação de equipes de manutenção (Beloch, 1986; Cardoso, 2010).
} 
(1992) afirma que esse processo de drenagem foi um dos exemplos mais perversos de agressão à natureza e de reprodução do capital praticado com o dinheiro público. De acordo com o autor, elevadas somas de dinheiro foram utilizadas na valorização das terras de grandes proprietários, que as adquiriram por preço baixo ou através de processos de grilagem, revendendo-as com significativas margens de lucro. Estas passaram a ser loteadas e vendidas para a população proletária, que foi expulsa para locais inóspitos, de modo a se transformar em mão de obra barata para as indústrias (Amador, 1992).

Enquanto isso, o aumento do número de estações e de viagens fez crescer a quantidade de passageiros que passavam pela vila de Merity. Lentamente, a infraestrutura progredia: com a continuação da EF Leopoldina rumo a Inhomirim, em 1911 já estavam em funcionamento, além de Merity, as estações de Gramacho, São Bento, Campos Elíseos, Primavera, Saracuruna e Parada Angélica; ${ }^{35}$ em 1916, foi instalada a primeira bica d'água na "velha estação de Merity" (Moraes, 1990); em 1924, foi instalada a primeira rede elétrica e fundada a Escola Proletária Merity; em 1928, foi inaugurada a estrada Rio-Petrópolis (Moraes, 1990; Cardoso, 2010).

A partir de então, a Baixada Fluminense, com destaque para Duque de Caxias, passou por um notável crescimento demográfico. Tamanha expansão populacional aumentou as demandas sociais, tendo sido acompanhada pelo fracionamento e o loteamento de antigas propriedades rurais que, naquele momento, estavam improdutivas. Tais loteamentos ${ }^{36}$ seguiram modelos diferenciados, o que nos permite considerá-los um dos vetores da segregação socioespacial no município fluminense. Portanto, neste ponto da análise, faz-se necessário analisar a dinâmica populacional e o processo de loteamentos em Duque de Caxias no decorrer do século XX, bem como seus efeitos sobre o território municipal.

\section{Duque de Caxias no século XX: de "cidade-dormitório" a cidade plena}

Até meados do século XX, a área que corresponde ao município de Duque de Caxias era um espaço predominantemente rural. Entretanto, a melhora da infraestrutura, a presença da Estrada de Ferro Leopoldina e o fim da ameaça da malária a partir dos anos 1930 tornaram o espaço baixadense

\footnotetext{
${ }^{35}$ A estação Parada Angélica, que, na época, se localizava em território iguaçuano, posteriormente viria a fazer parte do futuro município de Caxias.

36 Há duas versões para o início dos loteamentos urbanos no atual território de Duque de Caxias. Segundo Rogério Torres (2008) e Pierre Costa (2012), o primeiro loteamento legalizado de que se tem notícia na área do município é o Parque Artur Goulart, aprovado em 1914, junto à estação de Duque de Caxias, ainda chamada de Merity à época. Já de acordo com Guilherme Peres (2008) e Marlucia Souza (2012), "o primeiro loteamento feito em Merity foi realizado pelo engenheiro Abel Furquim Mendes, que, em 1918, dividiu uma área ao longo da via férrea, entre as ruas Pinto Soares e Manoel Reis. Esses lotes foram oferecidos a cinquenta mil réis cada. Entretanto, a venda foi um fracasso" (Peres, 2008, p. 203). Não foi possível identificar qual das duas versões é a correta.
} 


\section{Situando Duque de Caxias no contexto metropolitano da Baixada Fluminense}

relativamente atraente para a população. Em pouco tempo, DC e a Baixada passariam por um processo de ocupação desordenado, recebendo uma numerosa população pobre do Rio de Janeiro e de estados do Nordeste.

Isso ocorreu porque, desde o início do século XX, um conjunto de fatores fez com que as opções de moradia para a população de baixa renda na cidade do Rio de Janeiro diminuíssem. Afinal, o crescimento demográfico, o encarecimento dos terrenos e as políticas de erradicação dos cortiços na área central da então capital do país promoveram uma expulsão populacional. Com isso, os habitantes mais pobres do Rio de Janeiro, além dos muitos migrantes nordestinos, tiveram de escolher entre as favelas ou as recém-saneadas e acessíveis terras da Baixada Fluminense (Abreu, 1987). Em consequência, o intenso processo de favelização nos morros e de ocupação dos subúrbios e áreas mais periféricas ao núcleo da então capital federal pela população de baixa renda promoveu uma expansão horizontal do espaço urbano local. Servidos pelas ferrovias e atuando como palco de processos de loteamento popular e autoconstrução, esses espaços, gradativamente mais distantes, passaram a abrigar a massa trabalhadora do Rio de Janeiro (Pacheco, 1984).

Tal ocupação de áreas cada vez mais afastadas fez com que, em 1930, o tecido urbano já tivesse avançado sobre os limites do Distrito Federal, alcançando a Baixada Fluminense. Assim, suas terras serviam para aliviar a pressão demográfica da cidade do Rio de Janeiro, bem como para abrigar muitos dos expulsos pelo "Bota Abaixo" do prefeito Pereira Passos. ${ }^{37}$ A área da vila de Merity, atual centro da cidade de Duque de Caxias, que, no início do século XX "era uma incipiente estação ferroviária cercada por uma decadente área rural, dominada por uma também decadente classe dominante rural, cada vez mais ausente" (Costa, 2012, p. 217), começa a presenciar a expressiva chegada de novos habitantes. Segundo Torres (2008), a população da então Merity aumentou 365\% de 1910 a 1920 , passando de oitocentos habitantes para 2.920. Em 1930, já eram 28.756 seus moradores. Com isso, houve uma explosão da demanda por terras, que, por sua vez, promoveu intenso fracionamento das antigas propriedades rurais, o que levou ao surgimento dos loteamentos:

[...] diretamente do vazio econômico [...], suscitados pela abundância de terras baratas situadas nas proximidades da capital federal. A abertura [do novo traçado] da rodovia Rio-Petrópolis [paralela e contígua à EF Leopoldina,], inaugurada em 1928 e cruzando as várzeas que viriam a compor o município, desenvolveu extraordinariamente a atividade loteadora, ao facilitar a ligação de tais áreas com a cidade do Rio de Janeiro (Beloch, 1986, pp. 24-5).

\footnotetext{
${ }^{37}$ Segundo Márcio Piñon de Oliveira (2015), a intervenção urbanística conhecida como Reforma Pereira Passos (1902-1906), também chamada de "Bota Abaixo", buscava "solucionar os problemas de saneamento básico, ampliar as vias de circulação, como a abertura da avenida Central (atual Rio Branco) e investir no embelezamento da cidade, tornando-a, na expressão da época, 'digna de ser Distrito Federal', atraindo olhares estrangeiros, deixando para trás a cidade de estrutura colonial mercantil e abrindo espaço para a cidade industrial que se formava" (Oliveira, 2015, p. 2.638). Para mais informaçôes sobre a Reforma Pereira Passos, ver Abreu (1987), Pinheiro (2010) e Oliveira (2015).
} 
Assim, além dos loteamentos - predominantemente às margens da ferrovia -, cresciam as instalações fabris no entorno da nova rodovia. Logo, podemos afirmar que, a partir dos anos 1930, durante a Era Vargas, o território do atual município de Duque de Caxias experimentou intensivo processo de remodelação de sua área, incorporando-se ao modelo urbano industrial.

Cada vez mais desvinculada das atividades rurais e integrada à lógica de acumulação urbana, uma nova elite se forma gradualmente na cidade. Ao mesmo tempo, o tecido social caxiense se torna mais complexo com a chegada maciça de migrantes que ocupam o posto de mão de obra barata nas atividades urbanas locais e da capital federal. E, completando esse panorama, surge o controverso Tenório Cavalcanti, uma das novas lideranças que passa a efetuar um contraponto às elites tradicionais, mas que, em pouco modificou - e para alguns, até mesmo acentuou - a precária situação social da população do município, como veremos a seguir.

\subsection{As elites caxienses e o clientelismo: um entrave ao desenvolvimento local e um impulso para a segregação social}

A histórica política de Duque de Caxias foi fortemente impactada por práticas clientelistas, cujas açôes se basearam essencialmente no uso da máquina administrativa em benefício de poucos. Segundo Souza (2012), tem havido predomínio absoluto de lideranças políticas com perfis populistas e clientelistas ao longo das diversas gestôes e fases da história municipal no século XX. ${ }^{38}$ Longe de ser exclusividade caxiense, esse panorama é recorrente em outros municípios com formação e perfil semelhantes, como afirma Adauto Cardoso:

[...] tradicionalmente as prefeituras dos municípios mais pobres desenvolvem suas políticas dentro de um padrão clientelista tradicional, em que as açōes são fragmentadas e pontuais, atendendo a quase que individualmente às demandas, e segundo uma definição de prioridades que atende principalmente aos interesses político-eleitorais imediatos. Essa forma do "fazer política", que vigora preponderantemente na Baixada Fluminense, incorpora ainda a inadequação técnica, que transforma soluções em problemas futuros (Cardoso, 1998, pp. 1.699-1.700).

Dessa forma, historicamente, a população local tem dependido de quadros políticos que mantêm a popularidade alta por meio da concessão de benefícios pontuais. Assim, alcançam a legitimidade política necessária para permanecer no poder, sem que precisem resolver efetivamente os problemas existentes. Pelo contrário, até mesmo se beneficiam com a perpetuação desses problemas.

\footnotetext{
${ }^{38}$ Para mais detalhes sobre a questão política em Duque de Caxias, ver os trabalhos de Israel Beloch (1986), Rita Sales (1999), Manoel Cantalejo (2008) e Marlucia Souza (2012).
} 


\section{Situando Duque de Caxias no contexto metropolitano da Baixada Fluminense}

Em 1931, Merity foi elevada à condição de Distrito ${ }^{39}$ de Nova Iguaçu, com sede na antiga estação local, cuja placa de identificação já fora informalmente alterada por seus moradores ${ }^{40}$ como uma forma de romper com o passado negativo associado ao nome anterior. A nova configuração política "estabeleceu um novo eixo de poder, consolidando o que a mudança do traçado da Rio-Petrópolis havia começado" (Costa, 2012, p. 218). Assim, o agora Distrito de Caxias, $8^{\circ}$ do município de Nova Iguaçu, continuava a crescer rapidamente. Nas palavras de Costa:

[...] esse crescimento econômico resultou em novos moradores abastados, e se formaram novos grupos de interesse que procuraram se juntar em busca de reconhecimento enquanto lideranças locais. Assim, foi fundada a União Popular Caxiense (UPC) em 1933. [...] [Posteriormente, o] processo de emancipação de Caxias esteve relacionado ao grupo de jornalistas, médicos e políticos locais que organizou a UPC [...] (Costa, 2012, p. 218).

Assim, mesmo com a mudança de status jurídico, aumentava a insatisfação da elite local ${ }^{41}$ caxiense com o governo municipal de Nova Iguaçu. Tal situação aceleraria o processo de emanci-

${ }^{39} \mathrm{O}$ desenvolvimento pelo qual passava Merity levou Manoel Reis, então deputado federal, a propor a criação do município de Duque de Caxias. Dessa forma, através do Decreto Estadual n 2.559, de 14 de março de 1931, o interventor federal Plínio Casado elevou o local a $8^{\circ}$ Distrito de Nova Iguaçu.

${ }^{40}$ Até 6 de outubro de 1930, a primeira estação ferroviária de Caxias tinha o nome de Merity, devido à abundância desse tipo de palmeiras na região, nome que havia sido utilizado para batizar também o rio que nasce no sopé da Serra de Gericinó e deságua na Baía de Guanabara. O nome da estação ferroviária era motivo de chacota pelos moradores e a imprensa carioca, que chamava o lugarejo de "Merity do Pavor", pois a região era uma sucessão de brejos, onde proliferava a malária e onde faltava tudo. Com a chegada da água e de algumas obras de saneamento que melhoraram as condições de vida da população, incluindo o calçamento de algumas ruas e a instalação de um posto dos correios e telégrafos, o apelido de "Merity do Pavor" passou a incomodar. Foi então que um morador do local, José Luis Machado, que todos tratavam como Machadinho, teve a ideia de substituir a placa da estação ferroviária, mudando o nome do local. Com o apoio dos moradores, o nome escolhido foi "Caxias", uma homenagem a Luís Alves de Lima e Silva, o patrono do Exército Brasileiro, que nasceu na Fazenda São Paulo, em Imbariê, atual $3^{\circ}$ Distrito do município. Assim, no dia 6 de outubro de 1930 e numa ação espontânea, o povo acompanhou Machadinho numa invasão à estação ferroviária, onde a placa indicativa de Estação Merity foi substituída por outra, pintada apenas com "Caxias". Nas palavras do jornal O Municipal, "para cometer esse arroubo, Machadinho teve o apoio de Jaime Fischer Gamboa, Oswaldo Gamboa, Américo Soares e Francisco Azevedo, os únicos no grupo que estavam armados e que não enfrentaram qualquer tipo de reação dos funcionários da estação ferroviária. Atendendo à decisão do povo, o então interventor federal no antigo estado do Rio de Janeiro, Plínio Casado, subscreveu a mudança de nome da estação ferroviária, por meio do Decreto Estadual no 2.559, de 14 de março de 1931" (O Municipal, 2005, p. 5).

${ }^{41}$ Alegando que a presença do governo municipal era notada apenas através da coleta de impostos, uma comissão composta por membros da elite e políticos locais encaminhou, em 25 de julho de 1940, um memorial expondo os interesses emancipatórios de Duque de Caxias ao interventor estadual Amaral Peixoto. 
pação de Duque de Caxias, ${ }^{42}$ ocorrido em 1943 - por interesses que ultrapassavam a esfera local e que até hoje não estão plenamente esclarecidos. ${ }^{43}$ Porém, a emancipação de Duque de Caxias não levou à instalação de um aparato local com autonomia. Na prática, a cidade seria governada de 1944 a 1947 por interventores, ${ }^{44}$ nomeados diretamente por Amaral Peixoto e Getulio Vargas, gestores, respectivamente, dos poderes estadual e federal naquele momento. Logo, Caxias se transformou num território com baixíssima autonomia, a serviço do populismo e do discurso nacionalista de trabalho, ordem e progresso (Alves, 2003; Souza, 2012; Costa, 2012). Assim, a falta de infraestrutura urbana e de investimentos em cultura, lazer, saúde e educação consolidava o município como um depósito de trabalhadores braçais, influenciados pelo trabalhismo e pelas práticas clientelistas.

Tal contexto de carência social tornou-se campo fértil para a criminalidade germinar e crescer, o que era agravado pelo frágil sistema de segurança pública regional e local. Além disso, "a cobertura jornalística, centrada nas ações delituosas, ajudou a recair sobre Caxias a pecha de 'cidade do crime"” (Lacerda apud Costa, 2007, p. 113). Contribuiu ainda para essa fama a chegada de Natalício Tenório Cavalcanti (Figura 15), migrante alagoano que se consolidou como forte liderança política no município.

\footnotetext{
${ }^{42}$ Em 31 de dezembro de 1943, através do Decreto-Lei n ${ }^{\circ}$ 1.055, foi criado o município de Duque de Caxias. Somente em 1947, porém, foi eleito o primeiro prefeito por voto popular e instalada a Câmara Municipal.

${ }^{43}$ Há controvérsias sobre as razôes centrais que levaram ao processo de emancipação do município de Duque de Caxias. Manoel Simões (2015) explica que um dos principais fatores que levaram à criação do município foi a instalação da Fábrica Nacional de Motores (FNM) em Xerém, fundada por uma portaria federal de 1940 e inaugurada em 1945. De acordo com Simóes, o interventor federal queria um homem de confiança no comando do território que abrigaria esse empreendimento estratégico. Já Stélio Lacerda (2008) afirma que, ao governo do Estado, interessava conceder a emancipação de Caxias, pois isso permitiria organizar e aparelhar melhor a máquina arrecadatória de impostos e, ao mesmo tempo, ampliar as áreas de dominação política. Helenita Beserra da Silva (2003) defende que a emancipação se deu em função da política de Getulio Vargas, que, consciente das conjunturas de âmbito nacional e mundial, buscou criar na população um sentimento de nacionalidade, ao mesmo tempo que assegurava a organização do quadro territorial do país e podava o excesso de regionalismo, o qual, entre outras coisas, era base de sustentação das oligarquias rurais.

${ }^{44}$ Para consultar a lista de interventores nomeados em Duque de Caxias nesse período, ver Costa (2012, p. 222).
} 
Figura 15. Tenório Cavalcanti caminha pelas ruas de Caxias (1964)

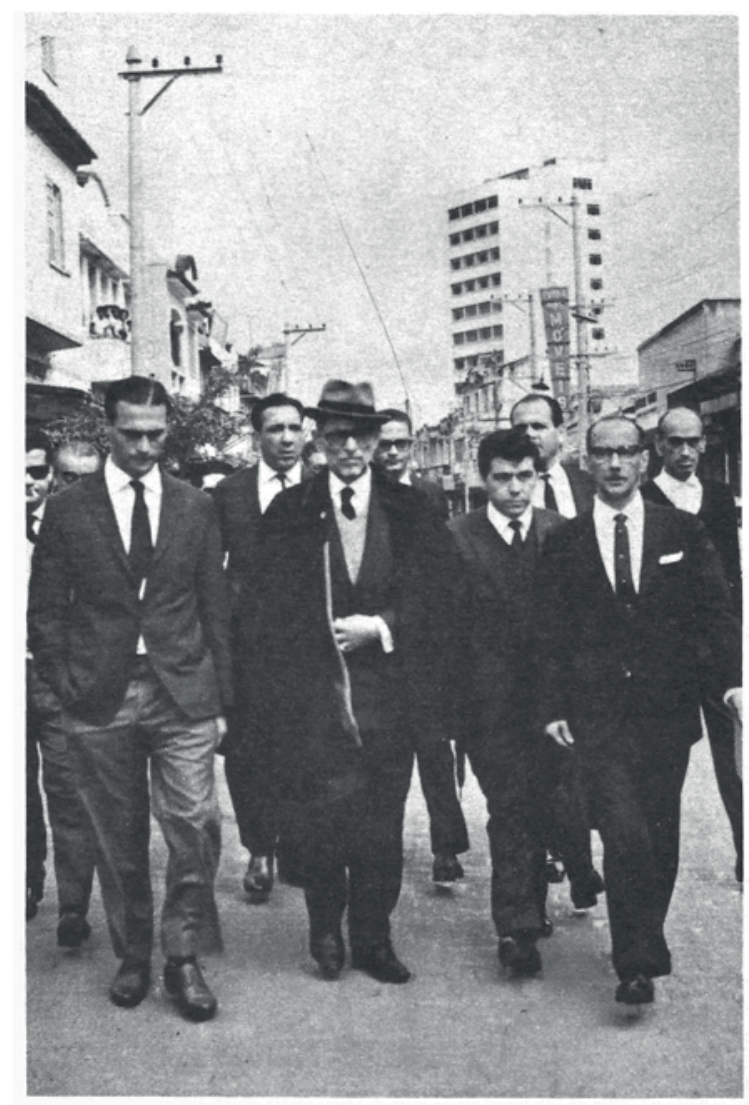

Fonte: Beloch (1986, p. 84).

Conhecido como "Homem da Capa Preta e da metralhadora Lurdinha", 45 Cavalcanti tornou-se um político importante, elegendo-se vereador e, posteriormente, prefeito de Duque de Caxias. Ganhou fama e popularidade também por sua atuação como advogado e jornalista. ${ }^{46}$ Durante a maior parte do tempo, ocupou uma posição política antigetulista, tendo combatido o aliado fluminense de Getulio, o interventor Amaral Peixoto. Essas disputas o fizeram envolver-se em uma série de atos

${ }^{45}$ Beloch (1986) e Alves (2003) afirmam que o apelido da metralhadora foi dado pelo motorista de Tenório, o "Anjo Negro". O nome seria uma associação irônica do som emitido pela arma com o das máquinas de costura, chamadas, carinhosamente, de "Lurdinha" pelas profissionais do ramo. Já Costa (2012) afirma que esse também era o apelido dado às metralhadoras pelos pracinhas da Força Expedicionária Brasileira (FEB) que estiveram nos campos de batalha italianos.

${ }^{46}$ Tenório foi fundador do jornal A Luta Democrática, criado em 1954, de circulação nacional e grande tiragem (Alves, 2003). 
de extrema violência, incluindo a morte de policiais e autoridades ${ }^{47}$ além de assassinatos cometidos por conta de desentendimentos e disputas de terras na cidade. ${ }^{48}$

Tenório migrou do Nordeste para o Rio de Janeiro em 1926, como tantos outros, em busca de oportunidades melhores. Sua trajetória de sucesso político teve início quando recebeu um convite, dois anos depois, para administrar uma fazenda no atual território de Duque de Caxias, então uma área de grande disputa de terras entre grileiros e lavradores. Ali, a resolução bem-sucedida de conflitos por meio da força fez prosperar "sua fama de pistoleiro e de boa pontaria" (Beloch, 1986, p. 46).

Nesse ambiente perigoso e violento, o sonho dos trabalhadores braçais que chegavam ao município de Duque de Caxias, de desfrutar uma vida digna, tornava-se ainda mais distante. Ao mesmo tempo, para proprietários, especuladores, empresas imobiliárias e setores articulados à sociedade política, Caxias representava o acesso a extensas propriedades e à chance real de lucros altos e rápidos. Tenório conseguiu sair do primeiro grupo e adentrar no segundo com grande êxito, tornando-se, ele também, um dos grandes proprietários do município. Seus defensores afirmam que o político colaborou para trazer hospitais, escolas públicas e melhorar o saneamento da cidade. Porém, há indícios claros de que também agiu como fomentador de desigualdades e práticas clientelistas.

Como exemplo, podemos apontar o caso da Vila São José, também conhecida como Vila do Tenório. Em 1971, o local contava com quase 12 mil habitantes, uma escola para cinco mil crianças e alguns cursos profissionalizantes. Porém, apesar de as mais de duas mil casas terem sido construídas com verba federal, passaram a ser de propriedade de Tenório, que cobrava dez cruzeiros de aluguel mensal por residência (Costa, 2012, p. 258). Gestos desse tipo corroboram as críticas de seus detratores, que denunciam sua atuação oportunista e clientelista. Além disso, na maior parte do tempo, sua atitude oposicionista acabou prejudicando a obtenção de verbas federais ou estaduais para financiar as obras públicas, tão necessárias ao desenvolvimento de um município profundamente carente de infraestrutura.

\subsection{Os anos 1940-1960: consolidação da cidade industrial - ou da cidade desigual?}

Nas duas décadas seguintes ao processo de emancipação, Duque de Caxias continuou a sofrer profunda transformação em seu perfil social e econômico. O município, que ainda era um núcleo aca-

\footnotetext{
${ }^{47}$ Segundo Costa (2007, p. 116), "foi dos anos 1950 a mais rumorosa explosão de violência em torno de seu nome: o assassinato do delegado de Duque de Caxias, Albino Imparato, e de outro policial, na madrugada de 28 de agosto de 1953. O atentado teria sido resposta de Tenório a um ataque a tiros que sofrera três dias antes e lhe deixara o chapéu furado à bala. Imediatamente Tenório foi acusado de mandante do crime”.

${ }^{48}$ Tenório Cavalcanti se defendia das acusaçôes dizendo-se alheio à matança ou tendo agido em legítima defesa (Alves, 2003). Internado em hospitais diversas vezes por conta do envolvimento em atos de violência, Cavalcanti "ostentava pelo corpo 47 cicatrizes de bala. Em certo momento, passou a usar colete à prova de bala, mas espalhava que tinha o corpo fechado” (Beloch, 1986, p. 16).
} 


\section{Situando Duque de Caxias no contexto metropolitano da Baixada Fluminense}

nhado no início da década de $1940,{ }^{49}$ tornou-se populoso e industrializado no fim dos anos 1950 . Essas mudanças vieram como resultado da implementação de políticas estatais de caráter nacionalista, uma vez que Caxias foi escolhido para abrigar instalaçōes fabris de grande porte a partir dos anos 1930-1940.

Num contexto marcado pelo início de descentralização da indústria fordista no espaço metropolitano, DC ganhava importância pela grande disponibilidade de terras a preços módicos, o que possibilitava às empresas manterem a proximidade com a capital federal, ao mesmo tempo que reduziam os custos de produção (Silveira, 2014). Por conta dessas vantagens, começaram a se instalar fábricas de pequeno porte dos setores têxtil, vidreiro, químico e farmacêutico (Petrakis, 2009). À mesma época, a União ampliou as áreas sob sua propriedade e nelas deu vazão a projetos como o Núcleo Agrícola São Bento, fundado em 1932; e à Cidade dos Meninos, ${ }^{50}$ núcleo de abrigo e educação para órfãos e crianças carentes criado entre 1942-1943. Contudo, o primeiro dos grandes projetos estatais em Duque de Caxias seria a criação da Cidade dos Motores, na localidade de Xerém, ${ }^{51}$ cujo núcleo central era a construção da Fábrica Nacional de Motores (FNM).

Inaugurada em 1945, a "Fenemê", como ficou conhecida, exigiu altos contingentes de mão de obra durante sua construção, num total de aproximadamente seis mil operários, além de suas famílias. A fábrica também atraiu camponeses do interior do estado fluminense e de outros estados, como Minas Gerais e Espírito Santo, que "vislumbravam a possibilidade de acesso à terra e de venda da produção agrícola para a Fenemê" (Costa, 2012, p. 227), além de muitos outros que passaram a buscar emprego na estatal. Porém, até o fim dos anos 1940, quando foram construídas as vilas operárias, os trabalhadores viviam em acampamentos fortemente hierarquizados e divididos em três classes: a dos operários da obra; a dos funcionários da administração; e a dos operários com formação técnica (Ramalho, 1989). Nas palavras de José Ramalho,

${ }^{49}$ Cabe citar, porém, que, apesar do núcleo urbano diminuto nos anos 1940, o município já apresentava características diferenciadas em relação aos demais vizinhos. Beloch (1986) afirma que Caxias era um dos poucos municípios fluminenses com algum destaque no setor industrial. Portanto, ali a indústria já era incipiente, e o que houve nos anos seguintes foi um desabrochar mais intenso a partir de uma conjuntura favorável.

${ }^{50} \mathrm{O}$ antigo núcleo da Cidade dos Meninos hoje é predominantemente desabitado, uma vez que houve contaminação pelos resíduos produzidos pelo Instituto de Malariologia e por uma fábrica de inseticidas, instalados na região em 1947 e desativados em 1962 (Rio Tóxico Tour, 2012).

${ }^{51}$ Segundo Ramalho (1989), a escolha da localidade de Xerém (atualmente, $4^{\circ}$ Distrito de Duque de Caxias e distante do centro do município) para sediar a FNM envolveu uma série de fatores. Ramalho enumera oito razões principais: Xerém era uma área estratégica, pela presença da estrada de Ferro Rio D’Ouro e da estrada Rio-Petrópolis, o que favorecia a comunicação e a chegada de equipamentos necessários à instalação da fábrica; o terreno no nível do mar diminuiria os custos de construção e logística; havia água em abundância, matéria-prima fundamental para a atividade industrial; havia áreas planas favoráveis à instalação de um campo de pouso; tratava-se de uma extensa área de terras vazias, o que facilitava sua transformação em propriedade da União; a área era protegida por serras e possuía apenas duas vias de acesso, o que a tornava ideal pela possibilidade de defesa de uma fábrica militar; e a proximidade de Xerém com a capital do país facilitava o acesso de técnicos e o escoamento da produção. 
[...] a diversidade de atividades nessa fase da fábrica teria servido de justificativa para a separação dos trabalhadores, assim como as diferentes fontes de recrutamento. [...] Embora predomine a explicação de que a maioria dos trabalhadores da construção civil fora recrutada de Minas e Rio, teria havido trabalhadores de outras regiōes do país, encontrados ou "apanhados" na Baixada Fluminense, principalmente Duque de Caxias, para o serviço duro de desbravar o terreno inóspito e construir os primeiros prédios (Ramalho, 1989, p. 62).

Assim, podemos considerar que muitos dos operários empregados na construção da indústria, bem como os trabalhadores do "chão da fábrica", tiveram de conviver com práticas segregadoras e discriminatórias nos primeiros anos do projeto.

Apesar das grandes expectativas depositadas na Fenemê e de seu relativo sucesso econômico por certo período, a fábrica não conseguiu atrair outros empreendimentos para o entorno. Até os dias de hoje, a localidade de Xerém mantém muitas características típicas de uma área rural. Portanto, podemos dizer que a Fenemê representou pouco para o destino industrial de Caxias, especialmente se comparada com a Reduc.

Foi apenas em 1961 que Duque de Caxias passou a contar com a grande responsável pelo desenvolvimento de sua economia e do setor industrial: a Refinaria de Duque de Caxias (Reduc), que se tornaria a "maior unidade industrial localizada na Região Metropolitana do Rio de Janeiro" (Costa, 2012, p. 230). Também instalada ali por conta da localização estratégica ${ }^{52}$ de Caxias, o peso da Reduc pôde ser sentido rapidamente na economia municipal: no final da década de 1970, a Reduc, o polo petroquímico em formação e a FNM, somados, eram responsáveis por 95,8\% da indústria local e empregavam 42,8\% da mão de obra ocupada no setor secundário (Beloch, 1986). Com isso, entre 1959 e 1970, a participação de Duque de Caxias nas atividades industriais da RMRJ aumentou de 4,4\% para 10,8\% (Beloch, 1986), e o município passou a apresentar a terceira maior arrecadação de impostos do estado. ${ }^{53}$ Ademais, era possível vislumbrar uma expansão ainda maior nos anos seguintes, uma vez que Caxias possuía a maior quantidade de terras livres entre todos os municípios da Baixada em 1970, além de metade de suas terras já ser urbana, o que aumentava as possibilidades de localização industrial (Costa, 2012). Tal panorama fez com que Caxias se tornasse "o município com o mais rápido avanço industrial não apenas na Baixada, mas em todo o antigo estado do Rio de Janeiro" (Costa, 2012, p. 240), cuja capital à época era Niterói. Na Tabela 3, é possível observar essa expansão industrial caxiense e o respectivo aumento das vagas de emprego associadas ao setor.

\footnotetext{
${ }^{52}$ Nas palavras de Costa, "as principais empresas petrolíferas procuram refinar o petróleo perto dos centros de consumo, de forma a reduzir os custos relativos de transporte e garantir a disponibilidade dos produtos nos principais centros consumidores" (Costa, 2012, p. 195). Portanto, tornava-se vantajoso para a empresa situar-se às margens da rodovia Washington Luiz e nas proximidades do segundo maior mercado consumidor do país, o Rio de Janeiro.

${ }^{53}$ Nos anos 1970, Rio de Janeiro, Volta Redonda e Duque de Caxias apresentavam, respectivamente, as três maiores arrecadações do estado do Rio de Janeiro (idem).
} 
Tabela 3. Indústrias e número de empregados em Duque de Caxias (1950-1983)

\begin{tabular}{|l|c|c|}
\hline Ano & Estabelecimentos Industriais & Número de Empregados \\
\hline 1950 & 112 & 3.287 \\
\hline 1956 & 172 & \\
\hline 1960 & 206 & 7.738 \\
\hline 1968 & 370 & \\
\hline 1975 & 504 & \\
\hline 1978 & 605 & \\
\hline 1983 & 826 & 26.000 \\
\hline
\end{tabular}

Fonte: Adaptado de Costa (2012, p. 241).

Com o surto industrial em curso, Duque de Caxias passou exercer a função de subcentro metropolitano, com uma área de influência que ultrapassava os limites do município e atingia até mesmo determinados bairros do então estado da Guanabara (1960-1975), atualmente cidade do Rio de Janeiro. Em consequência, começaram a crescer as vagas de emprego disponíveis em DC, mas ainda se mostravam insuficientes para atender à demanda de mão de obra, uma vez que a população local aumentava num ritmo muito acelerado. $\mathrm{Na}$ Tabela 4, observa-se que Caxias foi o município fluminense com a maior taxa de crescimento demográfico entre os anos 1950 e 1960.

Tabela 4. População nos municípios periféricos do Rio de Janeiro (1950-1960)

\begin{tabular}{|l|l|l|l|}
\hline Municípios & $\begin{array}{l}\text { População } \\
(\mathbf{1 9 5 0 )}\end{array}$ & $\begin{array}{l}\text { População } \\
(\mathbf{1 9 6 0 )}\end{array}$ & $\begin{array}{l}\text { Crescimento } \\
(\mathbf{1 9 5 0 - 1 9 6 0 )})\end{array}$ \\
\hline Duque de Caxias & 92.459 & 241.026 & $161 \%$ \\
\hline São João de Meriti & 76.469 & 190.516 & $149 \%$ \\
\hline Nova Iguaçu & 145.649 & 356.645 & $145 \%$ \\
\hline Nilópolis & 46.406 & 95.111 & $105 \%$ \\
\hline São Gonçalo & 127.267 & 244.617 & $92 \%$ \\
\hline Niterói & 186.309 & 243.188 & $31 \%$ \\
\hline Total & 674.552 & 1.371 .103 & $103 \%$ \\
\hline
\end{tabular}

Fonte: Elaborado a partir de dados de Costa (2012).

De modo geral, sabe-se que a Baixada Fluminense experimentou forte incremento populacional entre as décadas de 1940 e 1960, influenciada pela industrialização do Rio de Janeiro, principalmente nos governos de Getulio Vargas e Juscelino Kubitschek, associada à crescente expulsão dos trabalhadores braçais das áreas mais valorizadas da metrópole fluminense (Silveira, 2014). Contudo, o município de Duque de Caxias recebeu um contingente populacional em proporção maior que seus vizinhos, principalmente de levas de nordestinos em busca de oportunidades de trabalho e moradia. Isso se deve, em 
parte, à maior proximidade com o Rio de Janeiro, o que facilitava o deslocamento pendular diário em direção à metrópole. Como se nota na Tabela 5 , a maior parte da população de Duque de Caxias apenas estabelecia residência na cidade, obtendo seus proventos em atividades fora do município.

Tabela 5. Distribuição da população ocupada (PO) e da população ativa (PEA) nos setores industrial e de serviços em Duque de Caxias (1950-1970) $)^{54}$

\begin{tabular}{|l|c|c|c|c|c|c|}
\hline Ano & \multicolumn{4}{|l|}{ Setor industrial } & \multicolumn{2}{l|}{ Setor de serviços } \\
\hline & PO em DC & $\begin{array}{c}\text { PEA Total de } \\
\text { DC }\end{array}$ & $\begin{array}{c}\text { PEA que trabalha } \\
\text { fora de DC (\%) }\end{array}$ & PO em DC & $\begin{array}{c}\text { PEA Total de } \\
\text { DC }\end{array}$ & $\begin{array}{c}\text { PEA que trabalha } \\
\text { fora de DC (\%) }\end{array}$ \\
\hline 1950 & 3.287 & 11.811 & 72,2 & 2.000 & 14.181 & 85,9 \\
\hline 1960 & 7.738 & 21.770 & 64,5 & 4.730 & 42.512 & 88,9 \\
\hline 1970 & 14.261 & 48.028 & 70,3 & 12.333 & 74.610 & 83,5 \\
\hline
\end{tabular}

Fonte: Adaptado de Costa (2012, p. 246).

Portanto, fica claro que a forte onda migratória dessas décadas promoveu uma explosão demográfica em Caxias, ultrapassando a capacidade de absorção com padrôes mínimos de dignidade da população recém-chegada. Somente entre as décadas de 1940 e 1960, houve um aumento populacional de quase dez vezes, o que configura um crescimento rápido e acentuado. Nesse breve período de vinte anos, a população saltou de 29.618 para 243.626 habitantes, como se nota no Gráfico 5 .

Gráfico 5. Evolução da população do município de Duque de Caxias (1872-2000)

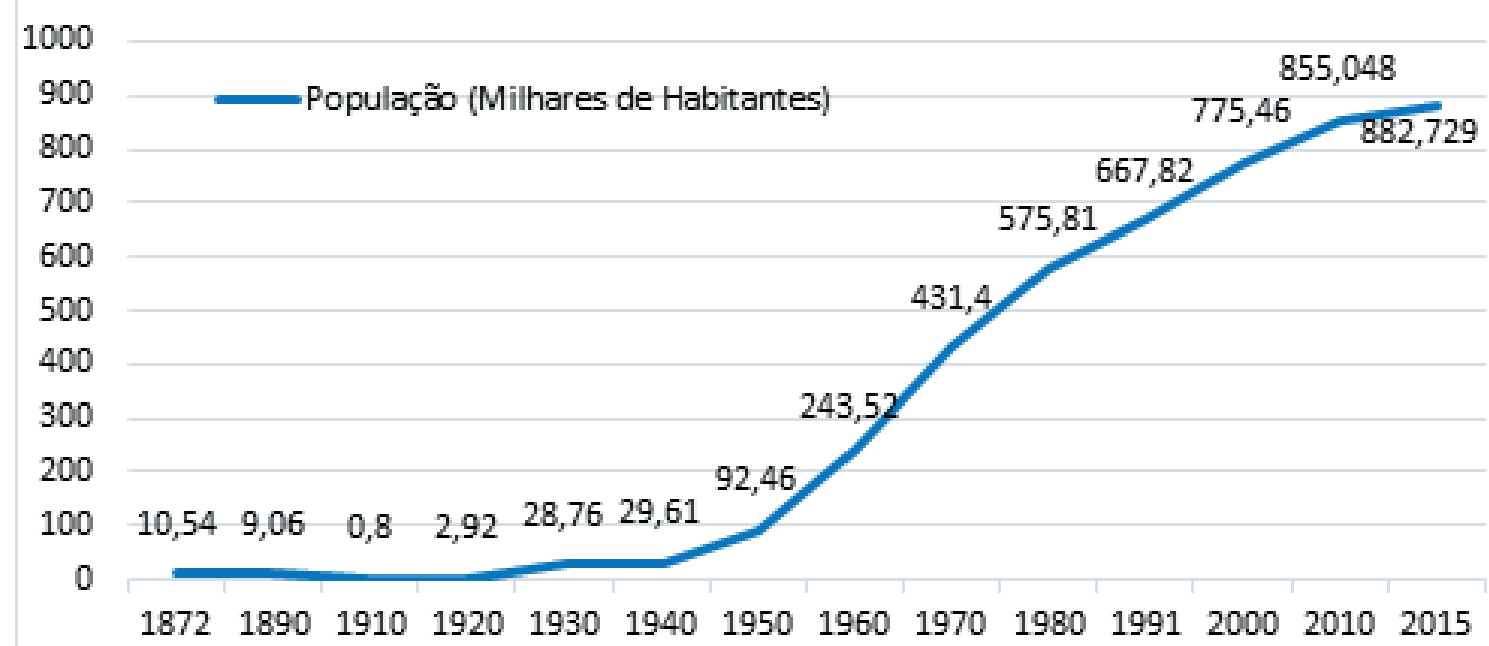

Fonte: Elaborado com dados de Lima (2010) e IBGE (2010 e 2015).

\footnotetext{
${ }^{54}$ Inclui as seguintes atividades: comércio, transportes, finanças, administração, defesa, profissōes liberais e serviços.
} 
Sem estrutura para atender a tamanho crescimento demográfico, Caxias assistiu ao crescimento dos problemas ligados à urbanização rápida e desordenada. De acordo com Braz e Almeida (2010, p. 70), "a precariedade no acesso à água potável, a ausência de uma rede de captação de esgoto e a precariedade nos serviços de energia tornavam a vida no município um flagelo às pessoas". Os censos de 1960 e 1970 mostram que menos de 25\% dos domicílios contavam com um escoamento de dejetos razoável (Beloch, 1986). Segundo Costa (2012), "[...] em 1970, dos 431.397 habitantes caxienses, apenas 30.284 trabalhavam no município. Desses, 12,18\% ocupavam-se na agricultura, $47,99 \%$ na indústria e $40,73 \%$ no comércio e serviços. [...] [Das] 109.513 edificaçôes, somente $40 \%$ eram ligadas à rede de água, $24 \%$ à de esgotos e $70 \%$ à energia elétrica (p. 243).

Dessa forma, o município passou a desempenhar "importante papel na fixação da população de baixa renda, que, face ao alto custo da terra, tem como opção [estabelecer] moradia em áreas periféricas, com reduzido investimento público" (Sales, 1999, p. 50). Consolidava-se uma típica estrutura urbana dicotômica, colocando em lados opostos as áreas centrais do Rio de Janeiro e as áreas periféricas. De modo geral, nas primeiras moravam as classes mais abastadas e o poder público era atuante, tendo criado relativa infraestrutura urbana. Já nos espaços suburbanos, morada das classes populares, os habitantes conviviam com a escassa infraestrutura, além de sofrerem com a indiferença do poder público no atendimento de suas necessidades mais básicas. Como resultado, a omissão - e, de certa forma, o respaldo - do poder público consolidou um espaço urbano caracterizado por forte desigualdade socioespacial. Com efeito, "para que fossem mantidos os ideais de ordem, eram necessárias desordens ignoradas ou imaginadas temporárias, como os loteamentos irregulares ou as favelas" (Petrakis, 2009, p. 51), multiplicando a quantidade de pessoas que viviam em condiçôes aviltantes. Todavia, quando observamos o ritmo de crescimento dessa população, verificamos que vem perdendo a força a partir da década de 1970, sendo relativamente baixo nos dias atuais (Gráfico 6).

Gráfico 6. Taxa de crescimento populacional em Duque de Caxias (1940-2010)

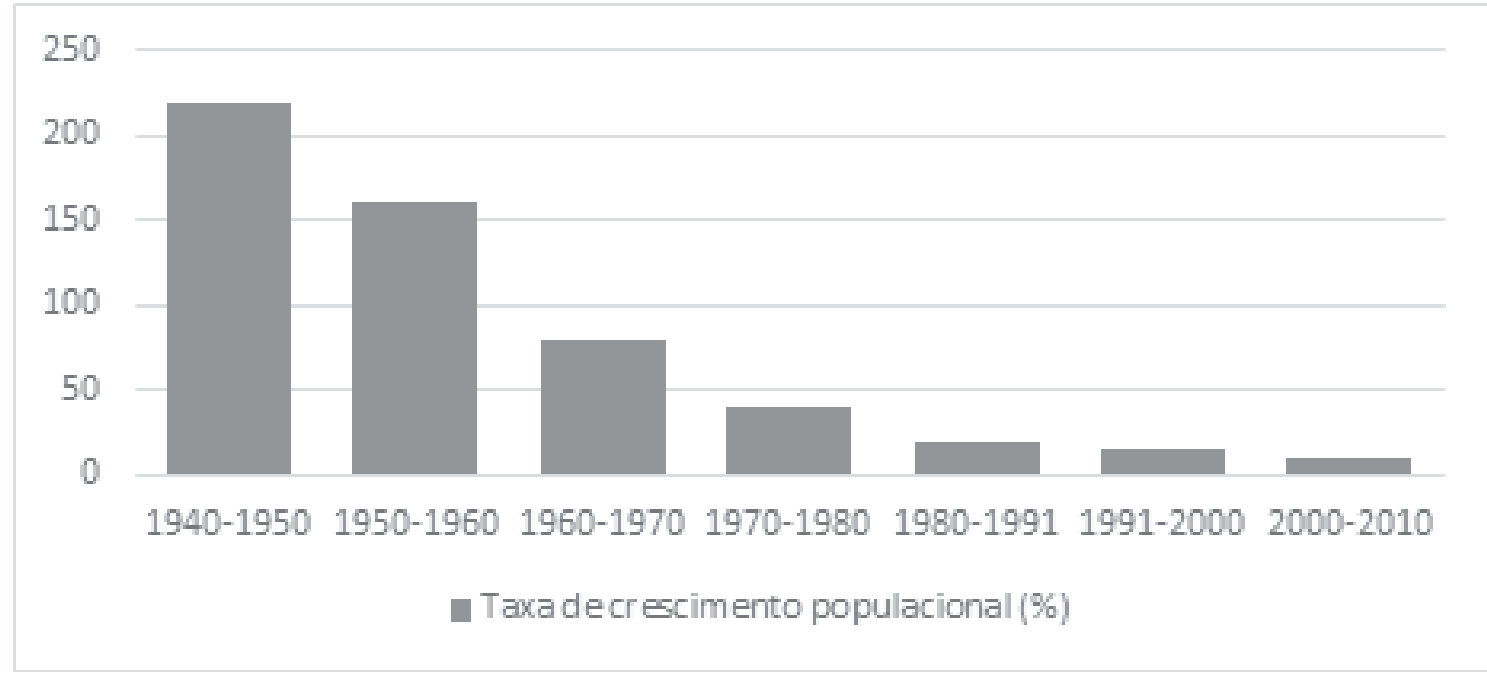

Fonte: Elaborado com dados do Ceperj (2013). 
A leitura do Gráfico 6 nos permite confirmar que o período de maior crescimento populacional no município ocorreu entre as décadas de 1940 a 1960. Nesse período, apesar da industrialização crescente, Caxias passou a apresentar uma ocupação típica de cidade-dormitório, com deficiência em todos os segmentos, tais como insuficiência de infraestrutura e equipamentos comunitários, implantação desordenada dos loteamentos e habitações de baixo padrão construtivo (Beloch, 1986). Portanto, julgamos que o processo de loteamento ocorrido entre as duas décadas promoveu impacto direto no município, acarretando uma grande transformação espacial, com mudanças no padrão de ocupação até então estabelecido e o consequente aprofundamento das desigualdades sociais existentes.

É possível notar que Caxias apresenta uma estrutura urbana no modelo centro-periferia, com infraestrutura, mercado de trabalho e moradia de alto padrão concentrados predominantemente nas áreas centrais, ao passo que a periferia municipal, em seus vários níveis, se mostra em sua maioria empobrecida. Ao mesmo tempo, assim como apontado por Lago (2000), a cidade conta com a presença de enclaves territoriais enobrecidos e outros em processo de enobrecimento, elementos vistos como característicos pela autora no novo padrão de segregação socioespacial na metrópole fluminense.

Nesse contexto, torna-se necessário investigar o fenômeno dos loteamentos em Duque de Caxias, especialmente nas duas décadas em que houve explosão do crescimento populacional, como forma de compreender as disparidades atualmente notadas entre os bairros do município.

\section{Os loteamentos e a produção de padrões de urbanização desiguais}

Segundo Pacheco (1984, p. 62), "a luta pela apropriação de um espaço de reprodução da força de trabalho pela população de baixa renda tem se processado praticamente do mesmo modo [...] desde que os loteamentos foram instituídos como forma de urbanização". Para a autora, as terras loteadas garantiam lucro para os capitalistas que as vendiam e resolviam o problema da moradia para os trabalhadores que desejavam ter um imóvel. Tal aparente simbiose de interesses faria, portanto, com que o padrão de ocupação das terras de áreas periféricas se mantivesse o mesmo por um longo período.

Nas glebas maiores, alguns proprietários que não tinham condições de arcar integralmente com os custos buscavam associar-se a empresas do núcleo metropolitano. Nesses casos, as empresas "assumiam os investimentos em obras de loteamento e venda dos lotes mediante a obtenção de parte dos lucros do empreendimento" (Pacheco, 1984, p. 33). No entanto, a maioria dos loteamentos em áreas periféricas tem como principal característica a pouca ou nenhuma infraestrutura. Costumam ser glebas rurais improdutivas, onde os empreendedores responsáveis apenas demarcam ruas e terrenos antes de efetuar a venda. Uma vez que o capital investido é próximo de zero, os lotes são revendidos a preços módicos. Normalmente, são oferecidas condições acessíveis de pagamento, com uma entrada simbólica, prestações reduzidas e, em geral, sem juros, o que torna os imóveis acessíveis à população de baixa renda (Simões, 2007). Após a compra do lote, os novos donos passam a efetuar a construção 
de suas residências por conta própria. Com a ajuda de amigos e familiares, muitas das vezes contrói-se até mesmo uma parte dos equipamentos coletivos do bairro. Tal regime, conhecido como "autoconstrução", acaba por formar:

[...] um grande número de bairros caracterizados pela baixa qualidade de vida reproduzindo, em parte, os mesmos problemas que haviam sido a causa do surgimento dos loteamentos. Se nestes não há mais amontoamento de pobres em ruas estreitas sem circulação de ar, a precariedade das construções e das condições sanitárias vão continuar assolando [...] [a população] e determinando uma degradação ambiental e das condições gerais de vida (Simões, 2011, p. 117).

Com efeito, a adoção do modelo de ocupação urbano baseado em autoconstruções realizadas em loteamentos permitiu transferir boa parte da pobreza e dos problemas sociais que atingiam a área central do Rio de Janeiro para áreas agora distantes da burguesia. Uma vez que as rápidas industrialização e expansão urbana sofridas pelo Rio de Janeiro promoviam crescimento expressivo da demanda por terras, a Baixada se mostrava uma área propícia a absorver a população excedente da capital federal.

Surgia, então, um movimento em direção às periferias que representou o lançamento das bases do que viria a se configurar a Área Metropolitana do Rio de Janeiro (Abreu, 1987). Nesse sentido, as vias de circulação tiveram participação fundamental, com destaque para as ferrovias. Afinal, a expansão da ferrovia permitiu o surgimento de diversos núcleos suburbanos, os quais passaram a ser habitados pela população pobre, que buscava moradia em locais de baixo custo. Dessa forma, mesmo com a construção de diversas e importantes rodovias na primeira metade do século XX, o trem continuou a ser o principal vetor de expansão populacional ao município de DC. Segundo Maurício de Abreu (1987), o transporte ferroviário facilitou muito o crescimento da metrópole "em pulos" (p. 123), devido às suas tarifas unificadas e subsidiadas pelo governo, o que permitia à população de baixa renda fixar residência em áreas de menor custo e afastadas do local de trabalho. Com isso, já nos anos 1930, diversos loteamentos começaram a ser realizados nas proximidades de estações ferroviárias dos distritos de Duque de Caxias, Nilópolis e São João de Meriti, mais próximos do núcleo metropolitano.

\subsection{Os loteamentos em Duque de Caxias e a "febre loteadora"}

O período de loteamento mais intenso no município de Duque de Caxias varia de acordo com o distrito em questão. Nos $2^{\circ}$ e $3^{\circ}$ distritos Duque de Caxias - Campos Elíseos e Imbariê, respectivamente -, os loteamentos foram feitos, em sua maioria, nas décadas de 1950 e 1970, como se vê na Figura 16. Porém, se, por um lado, Campos Elíseos possui a maior parte do seu território loteado, isso não se repete em Imbariê, uma vez que uma parte significativa de suas terras está em áreas rurais e de reserva florestal. 
Figura 16. Evolução urbana no município de Duque de Caxias

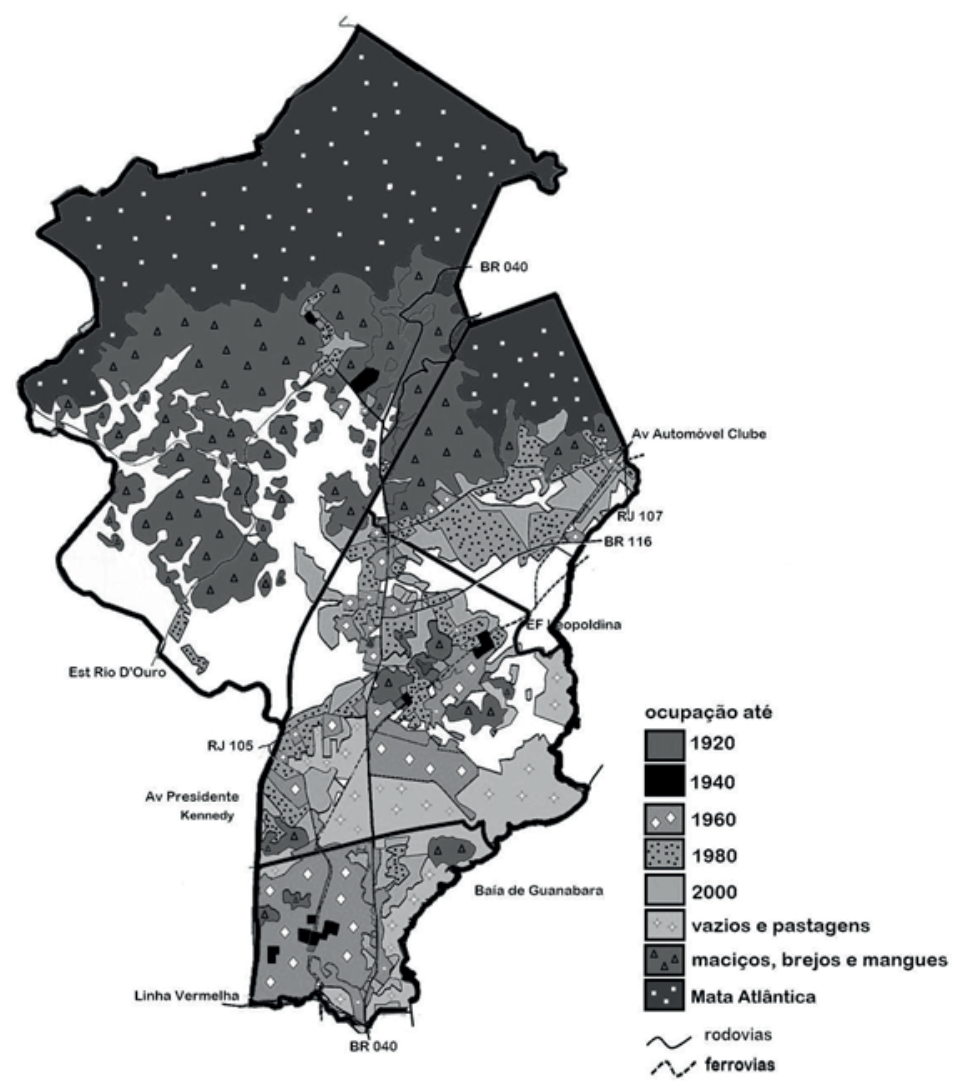

Fonte: Adaptado de Simões (2015, p. 31).

Já no distrito de Xerém, a ocupação esteve ligada inicialmente à construção da Fábrica Nacional de Motores (FNM). Como se nota na Figura 16, esse $4^{\circ}$ Distrito é o de menor área loteada, contando apenas com um conjunto de pequenas terras parceladas em sua sede e alguns bairros próximos. A observação dessa imagem nos mostra também que, atualmente, quase toda a área do $1^{\circ}$ Distrito está loteada. Ocupadas a partir da estação ferroviária central do município, suas terras foram mais parceladas entre as décadas de 1940 e 1960. Porém, é possível notar, nesse distrito, que alguns poucos espaços já estavam parcelados antes da década de 1940.

Isso ocorre porque é a partir dos anos 1920 e 1930 que Caxias começa a sofrer os primeiros efeitos mais expressivos da expansão urbana da cidade do Rio de Janeiro. É importante frisar que, em outras áreas da Baixada Fluminense, a fragmentação de terras começou antes mesmo do período de explosão demográfica. Nelas, o retalhamento de propriedades teve início durante o curto período econômico da citricultura, responsável por multiplicar as chácaras produtoras de laranja (Costa, 2012). Em Caxias, contudo, esse "ciclo" econômico não aconteceu. Essa é uma das razôes que explicam a maior quantidade de terras livres no território caxiense nas décadas de 1940 e 1950 em comparação com seus vizinhos da 
Baixada. Portanto, os loteamentos do município surgiram diretamente do vazio econômico, "suscitados pela abundância de terras baratas nas proximidades da cidade do Rio de Janeiro” (Beloch, 1986, p. 24).

O loteamento de terras, porém, alcançou seu auge entre as décadas de 1940 e 1960, momento em que todos os municípios da Baixada Fluminense apresentaram altas taxas de crescimento demográfico. Os fatores de atração que levaram a esse incremento populacional incluem a construção da rodovia Washington Luiz, ou BR-040 (1928), a inauguração da avenida Brasil (1946), da nova rodovia Rio-São Paulo, ou BR-116 (1951), a instalação da Reduc (1961), o baixo preço dos lotes oferecidos e o reduzido ou nenhum controle sobre as construçôes por parte do Poder Público, ao contrário do que acontecia na capital federal, em que as exigências burocráticas e a cobrança do cumprimento de normas urbanísticas tornavam mais difícil a construção de novos imóveis (Abreu, 1987).

Por causa dessas mudanças, Duque de Caxias passou a apresentar dois processos simultâneos de ocupação espacial: de um lado, aumentava a densidade dos loteamentos nas cercanias das ferrovias e da antiga Rio-Petrópolis; de outro, surgiam novos loteamentos e favelas às margens das novas rodovias construídas. Tal panorama colaborou para acelerar ainda mais o aumento populacional. Ocorreria, então, uma verdadeira "febre de loteamentos", como se pode observar na Tabela 6.

Tabela 6. Loteamentos aprovados pela prefeitura em Duque de Caxias (1949-1978)

\begin{tabular}{|l|c|c|c|}
\hline Período & $\mathbf{N}^{\circ}$ de lotes & Área total (ha) & $\begin{array}{c}\text { Área média dos } \\
\text { Lotes }\left(\mathbf{m}^{\mathbf{2}}\right)\end{array}$ \\
\hline Até 1949 & 57.206 & 6.198 & 1.083 \\
\hline $1950-1959$ & 85.642 & 7.001 & 817 \\
\hline $1960-1969$ & 60.038 & 3.274 & 545 \\
\hline $1970-1978$ & 27.988 & 1.376 & 492 \\
\hline Total & 230.874 & 17.849 & 773 \\
\hline
\end{tabular}

Fonte: Adaptado de Costa (2012, p. 231).

Nota-se que o período de maior intensidade do parcelamento de terras é a década de 1950, embora os loteamentos tenham continuado nas décadas seguintes. Porém, a cada década, as áreas médias dos lotes foram sucessivamente reduzidas. Podemos concluir que esse padrão indica a constante diminuição da oferta de terrenos em relação à demanda e, portanto, sua progressiva valorização. Ao mesmo tempo, demonstra o incessante declínio do padrão de vida dos compradores de lotes, constrangidos a se restringir a espaços cada vez mais acanhados - alternativa única à moradia em favelas (Silveira, 2014).

Essa febre de loteamentos nos anos 1950-1960, em Duque de Caxias, muito se relaciona com o processo radical de remoção das comunidades carentes na Zona Sul, na Zona Norte e no centro da 
cidade do Rio de Janeiro no período. ${ }^{55}$ Nesse momento, as áreas ocupadas pelas favelas começaram a ser disputadas pelo setor imobiliário, que buscava reproduzir seu capital em uma área já consolidada. A partir de então, o Estado assumiu a tarefa de remover as comunidades, o que permitiu liberar áreas para a especulação imobiliária e, ao mesmo tempo, aumentar o valor de troca das propriedades, ao eliminar a presença de algumas externalidades negativas, como a pobreza e a marginalidade ali existentes à época (Pacheco, 1984). Portanto, percebe-se que o Estado e os interesses do capital privado atuaram em conjunto na produção do espaço urbano nesse período, agravando o quadro já problemático da questão habitacional e induzindo a população mais pobre a se afastar do núcleo da metrópole, prejudicando, assim, sua capacidade de vivenciar os espaços mais valorizados da cidade.

Os promotores imobiliários passaram a priorizar a construção de seus empreendimentos em áreas nobres e, para isso, intensificaram a criação de amenidades e outras ações que pudessem aumentar o valor do solo urbano. Com a conivência das autoridades legais, essas medidas acabaram por impedir o acesso da classe baixa à moradia nesses locais, o que, por sua vez, ajudou a impulsionar mais o preço do solo como mercadoria. O Estado agiu da mesma forma, por meio de açóes diretas, como na remoção de favelas; ou indiretas, ao permitir a especulação urbana e os vazios espaciais nas áreas valorizadas da cidade. Com isso, o poder público deixou a uma grande parte da população poucas possibilidades de escolha, restando ir "para conjuntos habitacionais, para outras favelas ou para loteamentos recentes situados em localizações distantes e periféricas. Muitos optaram pela última escolha, dando novo impulso ao processo de periferização" (Pacheco, 1984, p. 18).

Tal processo de periferização atingiu Duque de Caxias de forma acentuada, transformando 38\% da área total do município em loteamentos já no fim dos anos 1960 (Beloch, 1986). Vista anteriormente, a Figura 16 permite notar que esse percentual não é maior porque muitos espaços municipais são ocupados por encostas, várzeas inundáveis, patrimônios públicos e outros terrenos não utilizáveis com esse finalidade, além de não terem sido computados os loteamentos clandestinos nessa estatística. Ao analisar o Quadro 1, constata-se que muitos dos principais bairros do município provêm de antigos loteamentos feitos entre as décadas de 1940 e 1950.

Quadro 1. Bairros caxienses e loteamentos de origem

\begin{tabular}{|l|l|c|}
\hline Bairro Atual & Loteamento de origem & Data de loteamento \\
\hline Imbariê & Vila Ema & 1942 \\
\hline Pauliceia & Parque Pauliceia & 1943 \\
\hline Figueira & - & 1943 \\
\hline Parada Angélica & Fazenda Tapera & 1945 \\
\hline Jardim Primavera & Chácara Rio-Petrópolis & 1947 \\
\hline
\end{tabular}

\footnotetext{
55 Segundo Abreu (1987), até a década de 1950 o Estado não se preocupou em remover as favelas dessas localidades, pela necessidade de manter uma reserva de mão de obra barata para as atividades econômicas ali situadas, pelos interesses políticos populistas e porque tais áreas eram economicamente pouco valorizadas até aquele momento.
} 


\begin{tabular}{|l|l|c|}
\hline Bairro Atual & Loteamento de origem & Data de loteamento \\
\hline Parque Paulista & Fazenda N. S. da Penha & 1948 \\
\hline Gramacho & Vila Leopoldina & 1950 \\
\hline Saracuruna & Vila Vitória & 1951 \\
\hline Jardim 25 de Agosto & Fazenda Engenho Velho & 1952 \\
\hline Dr. Laureano & Vila Caetano Madeira & 1952 \\
\hline Pilar & Nossa Senhora do Pilar & 1953 \\
\hline Lafayete & Parque Lafayete & 1956 \\
\hline Engenho do Porto & Fazenda Engenho do Porto & 1959 \\
\hline Pantanal & Vila Santo Antônio & \\
\hline
\end{tabular}

Fonte: Elaborado com dados de Braz e Almeida (2010, p. 82).

É preciso ter cuidado, contudo, com a generalização do processo de loteamento. Apesar do predomínio de um padrão de periferização constituído por loteamentos nas proximidades de estações ferroviárias e dotados de pouca ou nenhuma infraestrutura, não se pode afirmar que toda a urbanização de Duque de Caxias no período tenha seguido esse modelo. De acordo com Susana Pacheco,

[...] como forma de urbanização, [o loteamento] não tem sido um fenômeno genérico e sincrônico na periferia. Tampouco é provocado pelos mesmos fatores. Generalizar o loteamento a toda a extensão do que hoje denominamos periferia seria o mesmo que cometer o engano de esquecer o papel representado pela ocupação espontânea na configuração do espaço residencial metropolitano, sobretudo aquele que gerou núcleos constituídos a partir de estações ferroviárias (Pacheco, 1984, p. 28).

Logo, o loteamento não é necessariamente o único fator de urbanização de uma periferia, não é provocado pelas mesmas razões, nem segue os mesmos padrões sempre. Por isso, não é possível tratar as periferias e a áreas segregadas como espaços homogêneos. $\mathrm{O}$ interior das áreas periféricas também é palco de vários processos simultâneos e repleto de heterogeneidades socioespaciais, pois "os núcleos residenciais suburbanos também se expandiram criando suas próprias periferias, que, por sua vez, refletem com maior crueza as desigualdades desencadeadas a partir do núcleo metropolitano" (Pacheco, 1984, pp.18-9).

Nesse contexto, presume-se que nem todos os espaços de Caxias possuíam à época e hoje as mesmas precariedades infraestruturais. Isso porque, de acordo com Petrakis (2009, p. 55), o modelo de loteamento popular voltado a uso residencial apresentava duas vertentes distintas: a urbanização de status e a urbanização popular.

Sobre a primeira, pode-se dizer que "essas terras da periferia de amenidades são destinadas à população de status. Como se trata de uma demanda solvável, é possível aos proprietários fun- 
diários tornarem-se também promotores imobiliários; loteiam, vendem e constroem casas de luxo [...]” (Corrêa, 1989, p. 18).

Dessa forma, para atender aos anseios de uma classe mais abastada, surgiram no município alguns loteamentos dotados de melhor infraestrutura. Ali, o Estado se fazia presente, cobrando com rigor a adoção de padrões urbanos que tornavam os lotes mais caros e, por isso mesmo, inacessíveis aos mais pobres. Em Duque de Caxias, o exemplo mais evidente dessa urbanização de status é o bairro Jardim 25 de Agosto. Contudo, a maior parte dos demais bairros caxienses surgiu a partir de loteamentos que seguiram o padrão da urbanização popular. Segundo Corrêa (1989), esse modelo se caracteriza:

[...] [por ocorrer em] um setor periférico, não apenas distante do centro, mas sem amenidades, não atraindo, portanto, grupos sociais de elevado status [...] [Logo,] não resta aos proprietários fundiários senão o loteamento de suas terras como meio de extrair a renda da terra. E se trata de loteamentos populares, com o mínimo de infraestrutura. Tendo em vista o baixo poder aquisitivo da população que aí se desloca, não há interesse desses proprietários em se transformarem em promotores imobiliários. Apenas realizarão o loteamento; as habitaçôes serão construídas pelo sistema de autoconstrução ou pelo Estado (p. 19).

Dessa forma, supomos que, entre as décadas de 1940 e 1960, Caxias possuía poucos bairros com relativo ordenamento territorial. Por outro lado, deduz-se a existência de uma enorme quantidade de loteamentos precários. Afinal, era uma "cidade partida que crescia economicamente e separava-se socialmente em um mesmo movimento contínuo” (Braz e Almeida, 2010, p. 105). Portanto, acreditamos que o período situado entre as décadas de 1940 e 1960 é fundamental para que possamos entender de que forma se processou a produção do espaço urbano desigual no município de Duque de Caxias, uma vez que foi esse o momento de mais intenso crescimento populacional da cidade. Como também foi o auge do processo de loteamento, julgamos que alguns desses lotes receberam melhor infraestrutura e foram ocupados por uma população com renda mais elevada.

Historicamente rotulada como um espaço de alta criminalidade, a cidade de Duque de Caxias é também um ambiente propício para a absorção, por parte de seus moradores de renda mais elevada, da ideia de morar em condomínios fechados ou enclaves fortificados. Embasamos nossa visão a partir de Lago (2000), que apontou ser a periferia, já nos anos 1970, não mais apenas locus da pobreza, mas sim um espaço de precariedades, com a presença de novos enclaves territoriais enobrecidos e de outros em processo de enobrecimento.

Tal processo, ocorrido com a modernização do mercado imobiliário e a chegada de segmentos médios em determinadas localidades da periferia, teria se aprofundado no decorrer dos anos 1980 e 1990 e mantido ao longo dos anos 2000, promovendo, assim, uma contínua fragmentação do tecido socioespacial das cidades e complexificando o padrão de segregação até então observado nas metrópoles e em suas periferias.

Dessa forma, os indicadores de infraestrutura, renda e escolaridade tendem a apontar para a manutenção de uma estrutura urbana dual do tipo centro-periferia nos municípios da Região Metropolitana, embora cada vez mais fragmentada e entremeada por enclaves socioespaciais. Em Duque de 
Caxias, isso se confirma pela presença de núcleos abastados, especialmente no bairro Jardim 25 de Agosto, em que boa parte de seus habitantes desfruta de condições de renda muito superiores aos demais residentes do município. Assim, a ausência do Estado na condição de realizador de políticas efetivas de promoção da igualdade e da qualidade de vida para os cidadãos mais pobres promove também o aumento da mercantilização da segurança, em que as classes dominantes se ocupam da produção de um espaço urbano marcado pelo isolamento dos indivíduos.

\section{Referências}

ABREU, Maurício de Almeida. Evolução urbana do Rio de Janeiro. Rio de Janeiro: IplanRio/Zahar, 1987.

_ . "A luta pelo controle territorial da Baía de Guanabara no século XVI: agentes, alianças e conflitos". In ABREU, Maurício de Almeida (org.). Rio de Janeiro: formas, movimentos, representaçôes. Rio de Janeiro: Da Fonseca Comunicação, 2005, pp. 8-29.

ALVES, José Cláudio Souza. Dos barōes ao exterminio: uma história da violência na Baixada Fluminense. Duque de Caxias: APPH-CLIO, 2003.

AMADOR, Elmo da Silva. "Baía de Guanabara: um balanço histórico". In ABREU, Maurício de Almeida. Natureza e sociedade no Rio de Janeiro. Rio de Janeiro: Departamento de Documentação e Informação Cultural, 1992, pp. 201-58.

BELOCH, Israel. Capa Preta e Lurdinha: Tenório Cavalcanti e o povo da Baixada. Rio de Janeiro: Record, 1986.

BRAME, Fernando Ribeiro Gonçalves. "O desenvolvimento do conceito sociológico de cidade e a estrada de ferro como agente de articulação socioespacial". In SANTOS, Angela Moulin S. Penalva. Rio de Janeiro: um olhar socioespacial. Rio de Janeiro: Gramma, 2010. pp. 371-88.

BRAZ, Antônio Augusto e ALMEIDA, Tânia Amaro Augusto de. De Merity a Duque de Caxias: encontro com a história da cidade. Duque de Caxias: APPH-CLIO, 2010.

CANTALEJO, Manoel Henrique de Sousa. O município de Duque de Caxias e a ditadura militar: 1964-1985 (dissertação). UFRJ.

CARDOSO, Adauto Lucio. "Meio ambiente e moradia: discutindo o déficit habitacional a partir do caso da Região Metropolitana do Rio de Janeiro". Caxambu. Anais... XI Encontro Nacional da ABEP, 1998, pp. 1.671-703. Disponível em: http://www.abep.nepo.unicamp.br/docs/anais/ PDF/1998/a191.pdf.

CARDOSO, Alexandre. Retratos da Baixada Fluminense. Duque de Caxias: Wak, 2010.

CAVALCANTI, Nireu. "Rio, capital da colônia". In PINHEIRO, Augusto Ivan de Freitas (org.). Rio de Janeiro: cinco séculos de história e transformaçōes urbanas. Rio de Janeiro: Casa da Palavra, 2010, pp. 43-75.

CEPERJ. Anuário estatístico do estado do Rio de Janeiro. Fundação Centro Estadual de Estatísticas, Pesquisas e Formação de Servidores Públicos do Rio de Janeiro. Rio de Janeiro: Ceperj, 2013. Disponível em: http://www.ceperj.rj.gov.br/ceep/Anuario2013/index.html. Acesso em: 21 nov 2015. 
- Boletim CEPERJ: a estrutura industrial no Estado do Rio de Janeiro - 2008 a 2014. Ago 2014, ano I, no 3. Disponível em: http://www.ceperj.rj.gov.br/int/boletim\%20ceperj/Boletim_2014/ Boletim\%20n\%C2\%BA\%203\%20-\%20Agosto.pdf. Acesso em: 9 jan. 2016.

CORRÊA, Roberto Lobato. O espaço urbano. São Paulo: Ática, 1989. 94p.

COSTA, Pierre Alves. "Tenório Cavalcanti: entre o mito e a realidade”. In I Workshop Regional de Geografia e Mudanças Ambientais, 2007, Guarapuava. I Workshop Regional de Geografia e Mudanças Ambientais: desafios da sociedade do presente e do futuro. Anais... Guarapuava: Unicentro, 2007, pp. 113-20.

- A cidade do Petróleo: uma geo-história do refino do Petróleo no Brasil. Guarapuava: Unicentro, 2012.

FIGUERÊDO, Maria Aparecida de. A criação de um polo moveleiro no desenvolvimento econômico do município de Duque de Caxias: limites e perspectivas (dissertação). UFRJ, 2010.

GIMENEZ, Aurélio. "Moinho e fábrica naval se mudam para Duque de Caxias", O Dia, Rio de Janeiro, 08 abr. 2014. Disponível em: http://odia.ig.com.br/noticia/economia/2014-04-08/moinho-e-fabrica-naval-se-mudam-para-duque-de-caxias.html. Acesso em: 21 nov. 2015.

IBGE. PIB dos municípios brasileiros. 2010. Disponível em: ftp://ftp.ibge.gov.br/Pib_Municipios/2010/pdf/tab01.pdf. Acesso em: 28 nov. 2015.

LACERDA, Stélio. "De subúrbio dormitório a 'cidade progresso"”. In TORRES, Gênesis (org.). Baixada Fluminense: a construção de uma história. Rio de Janeiro: Inepac, 2008, pp. 199-202.

LAFRAIA, João Ricardo Barusso et al. REDUC 50 anos: entre o passado e o futuro. Rio de Janeiro: Petrobras, 2011.

LAGO, Luciana Corrêa. Desigualdades e segregação na metrópole: o Rio de Janeiro em tempo de crise. Rio de Janeiro: Revan, 2000.

LAMEGO, A. R. O homem e a Guanabara. Rio de Janeiro: IBGE, 1964.

LIMA, Marcos Rangel de. Desigualdades socioespaciais no municipio de Duque de Caxias, RJ: uma abordagem interescalar (dissertação). IBGE, 2010.

MCKENZIE, Roderick. "The Neighborhood: A study of local life in the city of Columbus, Ohio". American Journal of Sociology, v. 27, n. 2, 1921, pp. 145-68. Disponível em: http:// www.jstor.org/stable/2764821?. Acesso em: 06 set. 2015.

MORAES, Dalva Lazaroni de. O município de Duque de Caxias: sua terra, sua gente, sua economia. Rio de Janeiro: Ao Livro Técnico, 1990.

NOGUEIRA, Marcus Antonio Monteiro (org.). Baixada Fluminense: memória fotográfica. Rio de Janeiro: Inepac, 2008.

O MUNICIPAL, edição no 9.045, 21 a 28 de outubro de 2005, p. 5.

OLIVEIRA, Márcio Piñon de. "Cidadania e reformas urbanísticas no Rio de Janeiro: a Reforma Pereira Passos (1902-1906)". In A diversidade da geografia brasileira: escalas e dimensões da análise e da ação. Anais... Presidente Prudente: Anpege/Unesp-PP, 2015, pp. 2.636-48.

OLIVEIRA, Rafael da Silva. "Distintas noções de Baixada Fluminense: a busca do entendimento da constituição política da região - apresentação otimista sobre o seu crescimento latente". In (org.). Baixada Fluminense: novos estudos e desafios. Rio de Janeiro: Paradigma, 2004, pp. 17-47. 
PACHECO, Susana Mara Miranda. Produção e reprodução de loteamentos na periferia do Rio de Janeiro (dissertação). UFRJ, 1984.

PERES, Guilherme. "Notas sobre Duque de Caxias". In TORRES, Gênesis (org.). Baixada Fluminense: a construção de uma história. Rio de Janeiro: Inepac, 2008, pp. 203-4.

PETRAKIS, Giannis Hans Martins. O processo de verticalização e a especulação imobiliária no bairro 25 de Agosto, Duque de Caxias-RJ (monografia). UERJ, 2009.

PINHEIRO, Augusto Ivan de Freitas. "A cidade e o tempo: o Rio de Janeiro através dos séculos". In PINHEIRO, Augusto Ivan de Freitas (org.). Rio de Janeiro: cinco séculos de história e transformaçôes urbanas. Rio de Janeiro: Casa da Palavra, 2010, pp. 21-41.

PLANTEK, Consultores Associados. Planejamento Estratégico Municipal de Duque de Caxias. Duque de Caxias: Prefeitura Municipal de Duque de Caxias, 1999.

PNUD. Atlas do Desenvolvimento Humano no Brasil. Brasília: PNUD/São Paulo: IPEA/Belo Horizonte: Fundação José Pinheiro, 2013. Disponível em: http://www.atlasbrasil.org.br/2013/. Acesso em: 09 jan. 2016.

PRADO, Walter. História social da Baixada Fluminense: das sesmarias a foros de cidade. Rio de Janeiro: Ecomuseu Fluminense, 2000.

PUC. Núcleo Interdisciplinar de Meio Ambiente (NIMA). Atlas geográfico escolar do município de Duque de Caxias. Rio de Janeiro: PUC-RJ/Impressa Oficial do Estado do Rio de Janeiro, 2011.

RAMALHO, José Ricardo. Estado patrão e luta operária: o caso FNM. São Paulo: Paz e Terra, 1989.

SALES, Rita de Cássia Carneiro. Gestão local, saneamento e participação popular: reflexôes sobre o município de Duque de Caxias (dissertação). UFRJ, 1999.

SANTOS, Marcelo Ramos dos. "Duque de Caxias: um estudo da economia local”. In TENREIRO, André (org.). Duque de Caxias: a geografia de um espaço desigual. Nova Iguaçu: Entorno, 2015, pp. 65-87.

SEBRAE. Painel regional: Baixada Fluminense. Rio de Janeiro: Sebrae/RJ, 2015.

SILVA, Elizabeth Pessanha. A nova relação centro-periferia: reflexões a partir do município de Duque de Caxias (dissertação). UFRJ, 2014.

SILVA, Helenita Maria Beserra. "Emancipação política do município de Duque de Caxias”. Revista Pilares da História, Duque de Caxias, ano 2, n. 3, dez. 2003, pp. 28-36.

SILVA, Lucia Helena Pereira da. "A invenção da Baixada Fluminense: UUIO da FUNDREM (1975/89) e a representação de uma região". In XVI Enanpur - Encontro Nacional da Anpur, 2015. Belo Horizonte. Anais... Belo Horizonte, 2015, v. 16, pp. 1-14. Disponível em: http:// xvienanpur.com.br/anais/?wpfb_dl=616. Acesso em: 5 dez. 2015.

SILVEIRA, Leandro Almeida da. "Políticas públicas locais e a produção de desigualdades territoriais: o exemplo dos bairros Jardim 25 de Agosto e Pilar no município de Duque de Caxias”. Acta Geográfica (UFRR), 2014, v. 8, pp. 72-92.

SIMÕES, Manoel Ricardo. "Da Grande Iguaçu à Baixada Fluminense: emancipação política e reestruturação política e reestruturação espacial”. In OLIVEIRA, Rafael da Silva (org.). Baixada Fluminense: novos estudos e desafios. Rio de Janeiro: Paradigma, 2004, pp. 48-61. 
—. A cidade estilhaçada: reestruturação econômica e emancipaçōes municipais na Baixada Fluminense. Mesquita: Entorno, 2007.

- Ambiente e sociedade na Baixada Fluminense. Mesquita: Entorno, 2011.

—_. "Pequeno histórico da ocupação de Duque de Caxias". In TENREIRO, André (org.). Duque de Caxias: a geografia de um espaço desigual. Nova Iguaçu: Entorno, 2015, pp. 21-63.

SOUZA, Marlucia Santos de. "Entre o rural e o urbano-industrial: a produção de uma região moderna e as disputas políticas locais". Hidra de Igoassú: caderno de textos sobre história local e regional da Baixada Fluminense, Duque de Caxias, APPH-Clio, n. 1, fev. 2012, pp. 7-46.

TCE-RJ. Estudo socioeconômico dos municípios do estado do Rio de Janeiro 2014: Duque de Caxias. Rio de Janeiro: TCE-RJ, 2014.

TENREIRO, André et al. Atlas escolar do município de Duque de Caxias. 1 ed. Duque de Caxias: Secretaria Municipal de Educação de Duque de Caxias, 2012.

TORRES, Rogério. "Evolução histórica dos distritos e os processos de emancipação". In __ (org.). Baixada Fluminense: a construção de uma história. Rio de Janeiro: Inepac, 2008, pp. 195-8.

\section{Sítios eletrônicos consultados}

IBGE Cidades. Disponível em: http://www.cidades.ibge.gov.br/xtras/home.php Acesso em: 28 nov 2015.

RIO TOXICO TOUR. Disponível em: http://riotoxico.hotglue.me/caxias. Acesso em: 9 jan 2016. 